\title{
A new Barremian (Early Cretaceous) ichthyosaur from western
}

\section{Russia}

VALENTIN FISCHER, ${ }^{* 1,2}$ EDWIGE MASURE, ${ }^{3}$ MAXIM S. ARKHANGELSKY, ${ }^{4}$ and PASCAL GODEFROIT $^{2}$

${ }^{1}$ Département de Géologie, Centre de Geosciences, Université de Liège, Boulevard du Rectorat, SartTilman, 4000 Liège, Belgium, v.fischer@ulg.ac.be;

${ }^{2}$ Royal Belgian Institute of Natural Sciences, 29 Rue Vautier, 1000 Brussels, Belgium; Pascal.Godefroit@naturalsciences.be;

${ }^{3}$ Université Pierre et Marie Curie-Paris 6, UMR-CNRS 7207, CR2P, 4 place Jussieu, 75005 Paris, France, edwige.masure@umpc.fr;

${ }^{4}$ Geological Faculty, Saratov State University, 83, Astrakhanskaya ul, Saratov, 410026 Russia, paleozoo@gmail.com

RH: FISCHER ET AL.-NEW BARREMIAN ICHTHYOSAUR FROM RUSSIA

*Corresponding author. 
ABSTRACT - A new ophthalmosaurid ichthyosaur, Sveltonectes insolitus gen. et sp. nov., is described from a sub-complete and three-dimensionally preserved specimen from the late Barremian of western Russia. This new taxon is supported by 11 cranial, dental, and postcranial autapomorphies, and is also characterized by features previously considered as autapomorphic for some other Ophthalmosauridae, such as a processus narialis on the prefrontal and relatively long hindfins with pre- and postaxial accessory digits. We conducted a new phylogenetic analysis of Thunnosauria, which supports a 'Stenopterygius-origin' for Ophthalmosauridae. Sveltonectes is regarded as the sister taxon of Aegirosaurus, which shares a similar skull roof construction. Contrary to most other Cretaceous ichthyosaurs, Sveltonectes is characterized by delicate and sharply pointed teeth, confirming that the Ophthalmosauridae were ecologically highly diversified during the Early Cretaceous. 


\section{INTRODUCTION}

Ichthyosaurs were a successful group of marine reptiles ranging from the Olenekian (Early Triassic) to the Cenomanian (earliest Late Cretaceous; Bardet, 1992, 1994, 1995; Motani, 2005). Their Cretaceous record is limited, resulting in an apparent drastic diversity drop from the Jurassic to the Cretaceous (Bardet, 1994; Lingham-Soliar, 2003). During the Barremian, ichthyosaurs diversified with the appearance of the genus Platypterygius, firstly in South America and Australia (Platypterygius sachicarum, Paramo, 1997; Platypterygius hauthali, Fernández and Aguirre-Urreta, 2005; Platypterygius sp., Choo, 1999; Kear, 2003). This genus then reached a cosmopolitan distribution during the Aptian (Broili, 1907; Kear, 2003; VF, pers. obs.). On the contrary, very few Barremian ichthyosaurs are known so far in the Northern Hemisphere. Here we describe a new, nearly complete, and threedimensionally preserved late Barremian ichthyosaur from the Ul'yanovsk region in Russia. The specimen was first acquired by a German collector during the 1980s and then deposited in the collections of the Royal Belgian Institute of Natural Sciences (Brussels, Belgium). Small portions of the original matrix left in the skull, centra, neural arches, and phalanges were sampled for palynomorph analysis, in order to assess the authenticity and to reveal the age of the specimen. The Barremian strata of the same area (Ul'yanovsk region) have already yielded ichthyosaur remains, described by Bogolubow (1909) as 'Ichthyosaurus' steleodon. That taxon is an indeterminate ichthyosaur that is twice the size and more robust than the new taxon presented here.

Institutional Abbreviations-CR2P, Centre de recherche sur la paléobiodiversité et les paléoenvironnements; IRSNB/RBINS, Royal Belgian Institute of Natural Sciences, Brussels, Belgium; MHNH, Museum d'Histoire naturelle du Havre, Le Havre, France; RGHP, Réserve naturelle Géologique de Haute-Provence, France; SNHM, Staatliches Naturhistorisches Museum, Braunschweig, Germany; UPMC, Université Paris 6 Pierre et Marie Curie, Paris, France.

AGE

A dinoflagellate assemblage was extracted from the soft and calcareous marls using fluoric acid. Thirteen slides containing dinoflagellates were produced from the sampled matrix. These were analyzed at the CR2P laboratory (UMPC). The diversity of dinocysts is high, reaching a total of thirty-five taxa (Supplementary Data 1). The co-occurrence of the species Pseudoceratium pelliferum, Sirmiodinium grossii, Trichodinium speetonense, Batioladinium longicornutum, and numerous Cassiculosphaeridia magna indicates a late Barremian age for the specimen. Indeed, T. speetonense (Fig. 1S, D) appears during the Barremian, and both P. pelliferum (Fig. 1S, B), S. grossii (Fig. 1S, C), B. longicornutum (Fig. 1S, E), and C. magna (Fig. 1S, A) disappear at the end of the Barremian (Costa and Davey, 1992; ICS, 2006). Phoberocysta neocomica (Fig. 1S, F) is a long-range species (Rhyazanian-Aptian). The palynofacies of the matrix samples extracted from the rostrum, the orbit, the phalanges, the neural arches and indeterminate bone remains are identical (Fig. 1S, G). Only one poorly preserved centrum that was slightly larger than the others was characterized by a different dinoflagellate assemblage, containing lots of black organic particles (Fig. 1S, H). That centrum thus probably originates from different sediments, although poorly preserved specimens of the upper Barremian marker $T$. speetonense have been recognized in the matrix surrounding that centrum. Nevertheless, the centrum was removed from the specimen.

\section{SYSTEMATIC PALEONTOLOGY}

Order ICHTHYOSAURIA Blainville, 1835

Family OPHTHALMOSAURIDAE Baur, 1887 
SVELTONECTES INSOLITUS, gen. et sp. nov.

(Figs. 1-7)

Etymology_From Greek 'sveltos', agile or nimble, and 'nektes', swimmer, to account for the small size, streamlined skull, and inferred powerful girdle musculature of this ichthyosaur, and from the latin 'insolitus', unusual, to account for the numerous unusual features of this ichthyosaur, as well as its general bauplan and tooth morphology.

Diagnosis - Ophthalmosauridae characterized by the following autapomorphies: naris subdivided by extreme development of the descending process of the nasal; prootic perforated by a mediolateral foramen (reminiscent of Triassic ichthyosaurs such as Mixosaurus: Maisch et al., 2006); deep anteroventral fossa on the basioccipital; basipterygoid processes reduced to short rods; exoccipital with anterior pillar-like process; prominent, forked posterior process on the pterygoid; very small (tooth length index of 0.15 ), sharply pointed, and sometimes recurved teeth; acromion process of the scapula very prominent, rectangular, and lamellar dorsally; radiale, intermedium, and ulnare pentagonal with flat proximal surface and angular distal surface, allowing direct articulation of all (four) primary digits in a tightly packed polygonal fashion (reminiscent of Ichthyosaurus: McGowan and Motani, 2003); little or no contact between radius and intermedium, the intermedium being directly articulated with the ulna; presence of anterior and posterior accessory elements on the zeugopodial row of the hindfin.

Sveltonectes insolitus is also characterized by a unique combination of characters presented in Supplementary Data 1.

Holotype-IRSNB R269, a nearly complete skeleton.

Locality and Horizon-Ul'yanovsk region, western Russia; upper Barremian, Lower Cretaceous.

\section{DESCRIPTION}

\section{Skull roof}

The skull is laterally compressed and lacks most of its right side. The left side is complete and articulated. A calcite-mineralized fault displaced the postorbital region of the skull dorsally by $3 \mathrm{~cm}$ (Fig. 1). Measurements and ratios can be found in Table 1.

Premaxilla-The premaxilla is slender and its height decreases abruptly $2 \mathrm{~cm}$ anterior to the external naris. Unlike Ophthalmosaurus icenicus or Brachypterygius (Kirton, 1983), the premaxilla lacks a processus supranarialis. Posteriorly, the dorsal surface of the premaxilla becomes gutter-like and participates in the anteroventral border of the external naris. The fossa praemaxillaris is continuous on its whole length, from the very tip of the rostrum to the level of the external naris. Anteriorly, this sulcus is so deep that the tip of the rostrum looks X-shaped in anterior view. In many other ophthalmosaurids (Aegirosaurus, Ophthalmosaurus, Platypterygius, Brachypterygius), the fossa praemaxillaris ends anteriorly as a series of small, shallow foramina (Kirton, 1983; Bardet et al., 1997; Bardet and Fernández, 2000; Fischer et al., 2011; VF, pers. obs.). The premaxilla articulates with the maxilla along a straight suture starting $52 \mathrm{~mm}$ posterior to the emergence of the nasal. The premaxilla-lacrimal external contact was probably broad because the maxilla is very low, but this region is poorly preserved.

Maxilla-The dentigerous maxilla is very low, triangular in shape in lateral view, and its anterior process is strongly reduced, barely extending anteriorly to the external naris, as in some European specimens of Platypterygius (Sirotti and Papazzoni, 2002; VF, pers. obs.), Aegirosaurus (Bardet and Fernández, 2000), and Plutoniosaurus bedengensis (Efimov, 1997). Its lateral surface is slightly concave. 

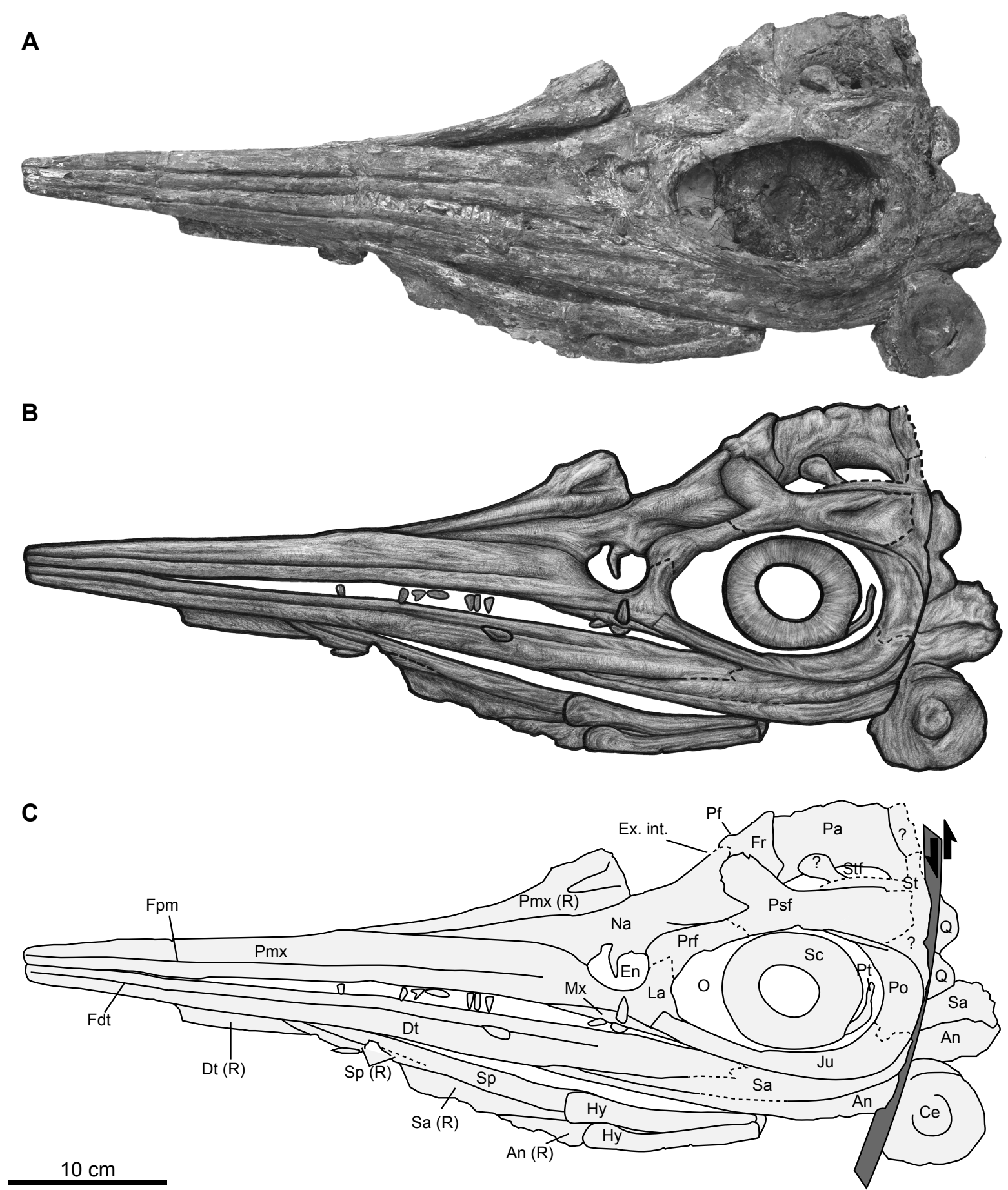

FIGURE 1. Skull of Sveltonectes insolitus (IRSNB R269) in lateral view. A, photograph. B, drawing. C, interpretive outline. The dark gray area in $\mathrm{C}$ represents the fault plane, and the arrows indicate the shear sense. Abbreviations: An, angular; Ce, centrum; Dt, dentary; En, external naris; Ex. int., excavatio internasalis; Fdt, fossa dentalis; Fpm, fossa praemaxillaris; Fr, frontal; Hy, hyoid; Ju, jugal; La, Lacrimal; Mx, maxilla; Na, nasal; O, orbit; Pa, parietal; Pmx, premaxilla; Pf, parietal foramen; Po, postorbital; Prf, prefrontal; Psf, postfrontal; Pt, pterygoid; Q, quadrate; Sa, surangular; Sc, sclerotic ring; Sp, splenial; St, supratemporal; Stf, supratemporal fenestra.

TABLE 1. Measurements (in $\mathrm{cm}$ ) and ratios of Sveltonectes insolitus (IRSNB R269). All ratios with respect to jaw length. 


\begin{tabular}{lll}
\hline Feature & Measurement & Ratio \\
\hline Prenarial length & 33 & 0.56 \\
Snout depth & 2.8 & 0.047 \\
Jaw depth & 3 & 0.051 \\
Orbit length & $13\left(7.7^{*}\right)$ & $0.18 \dagger$ \\
Pre-maxillary length & 30.2 & 0.51 \\
Snout length & 37.8 & 0.64 \\
Jaw length & 59 & - \\
\hline
\end{tabular}

Note: *orbit height; $\uparrow$ based on average of orbit length and height.

Nasal-The nasal contacts the premaxilla over a long and straight suture that bends ventrally $21 \mathrm{~mm}$ anterior to the external naris. A minute internasal foramen is present. As in Platypterygius australis and Platypterygius hercynicus an elongate ridge borders the excavatio internasalis laterally (Kear, 2005; Fischer, in press). The posterior parts of both the internasal foramen and the excavatio internasalis are formed by the frontal, as in P. hercynicus (Fischer, in press). The nasal forms the anterodorsal and dorsal borders of the external naris. The ventral border of the nasal forms a protuberant hook-like descending process that nearly contacts the ventral floor of the external naris (Fig. 1).

Lacrimal-Unlike in P. australis and Athabascasaurus, the lacrimal participates in the posterior border of the external naris (Kear, 2005; Druckenmiller and Maxwell, 2010). Dorsally, the lacrimal contacts the prefrontal along a sinusoidal suture. The lacrimal forms a rounded bulge that contacts the orbit and is continuous with the supraorbital flange.

Prefrontal-The anterior portion of the prefrontal forms a transversely-compressed processus narialis between the nasal and the lacrimal, which contacts the external naris as in Aegirosaurus (Bardet and Fernández, 2000). A small prefrontal-external naris contact is also present in O. icenicus (Kirton, 1983). The whole posterior part of the prefrontal is dorsoventrally compressed and forms the anterior portion of the prominent supraorbital flange.

Frontal-The frontal participates in the anterior margin of the supratemporal fenestra (like in $P$. australis: Kear, 2005; Aegirosaurus: Bardet and Fernández, 2000; P. hercynicus: Fischer, in press), thus separating the parietal from the postfrontal. It also participates in the lateral and posterior margins of the internasal foramen and it encloses the ovoid parietal foramen, although not via a thickened ring as in $P$. hercynicus (Fischer, in press).

Postfrontal-The anterior portion of the postfrontal is Y-shaped and forms an anteromedial fanshaped ramus that articulates with the frontal and the nasal, and an anterolateral ramus that contacts the prefrontal. The embayment between the anterior rami forms a wide and shallow groove posteriorly. Laterally, the postfrontal participates in the dorsal margin the orbit, forming the median part of the prominent supraorbital flange.

Parietal-The ventral surface of the parietal is subdivided in two deeply concave portions separated by a transverse concavo-convex tentorial ridge (like in Ophthalmosaurus: Andrews, 1910). This complex surface probably represents dorsal folding of the brain surface (Andrews, 1910; Kear, 2005). Dorsolaterally, the bone plunges ventrolaterally, forming the medial margin of the supratemporal fenestra. Unlike in P. australis (Kear, 2005), the dorsal surface of the parietal is flat and there is no parietal ridge. The anterior margin of the parietal forms a crenate and oblique articulation with the frontal, similar to that of Ophthalmosaurus (Kirton, 1983), whereas that suture is transverse in Platypterygius (Kear, 2005; Kolb and Sander, 2009; VF, pers. obs.). The elongated supratemporal process of the parietal and the medial ramus of the supratemporal articulate in a tongue-in-a-groove 
fashion. A posteromedian excavation on the parietal for the supraoccipital is present, although not as deep as in P. hercynicus (Fischer, in press) and Athabascasaurus (Druckenmiller and Maxwell, 2010).

Postorbital-Dorsally, the postorbital is rod-like and slightly compressed dorsoventrally, with a teardrop-shaped cross-section. Ventrally, the postorbital is a thin and slightly concavo-convex and forms a S-shaped suture with the jugal. The ventral part of the postorbital is undulating, as in P. australis (Kear, 2005).

Jugal-The anterior rod-like process of the jugal contacts the maxilla anteroventrally, and covers the lacrimal anteriorly and anterodorsally as in many ophthalmosaurids (Druckenmiller and Maxwell, 2010).

Quadrate - The stout and crescentic quadrate closely resembles that of $O$. icenicus in having markedly expanded dorsal and ventral extremities (Andrews, 1910; Kirton, 1983). In dorsal view, two distinct lamellae form an angle of ca. $100^{\circ}$. The anterior pterygoid lamella is plano-concave and oblique anteromedially. Ventrally, the pterygoid lamella bends laterally to form the medial side of the articular condyle. The articular condyle is reduced anteriorly and saddle-shaped (unlike some European species of Platypterygius that have an extremely massive articular condyle Kolb and Sander, 2009; VF, pers. obs.). The anterior and dorsal edges of the pterygoid lamella bear deep, irregular central incisions, indicating the presence of cartilage in vivo. The stapedial facet is markedly concave and its ventral edge is raised, unlike in some species of Platypterygius (VF, pers. obs.).

Sclerotic Ring-The left sclerotic ring is complete. It is composed of at least 10 articulated trapezoidal plates. Their external surface is textured by numerous radial striations. The sclerotic aperture is $43 \%$ the size of the sclerotic ring, and $12 \%$ the size of the orbit. This markedly differs from adult Ophthalmosaurus, the only thunnosaurian for which the sclerotic aperture reaches $20 \%$ the size of the orbit according to Fernández et al. (2005).

Pterygoid-The pterygoid lacks its anterior end. The anterior palatal ramus is twisted and dorsoventrally compressed, with a teardrop-shaped cross-section. The thicker posterior part of the pterygoid forms lateral, dorsal, and medial lamellae (Fig. 2G, H). The lateral lamella is the smallest, and it is slightly down-turned in the same plane than the dorsal lamella. The dorsal lamella is the thickest and the most prominent. It is oblique and faces dorsolaterally. Its medial surface is saddle-shaped and bears anteroventrally a deep rectangular incision receiving the basipterygoid process of the parabasisphenoid. This region is pitted and rugose, especially posteriorly to the basipterygoid facet, suggesting the presence of cartilage in life. The posterior edge of the dorsal lamella bears a large concave area that buttressed the shaft of the stapes. The pterygoid is unusual in forming a prominent posterior process with a kidney-shaped cross-section. These two lobes produce into acute bulges, giving the posterior process a forked end (Fig. 2G, H).

Parabasisphenoid-The basisphenoid is trapezoidal in lateral view and pentagonal in dorsal view (Fig. 2M, O). It is completely fused to the posterior end of the parasphenoid. The posterior surface of the basisphenoid is roughly circular and bears a deep incision that extends on the dorsal surface as a shallow groove. This feature is common amongst post-Triassic ichthyosaurs (e.g., McGowan, 1973; Kirton, 1983; McGowan and Motani, 2003; Kear, 2005; VF, pers. obs.). The dorsal surface of the basisphenoid is kidney-shaped, unlike those of P. australis (hexagonal, Kear, 2005), Brachypterygius (squared, McGowan and Motani, 2003) and O. icenicus (rounded, Kirton, 1983). The basipterygoid processes are reduced to short, right-angled, and dorsoventrally compressed rods (Fig. 2M, N, O). The carotid foramen is a deep furrow on the ventral side of the basisphenoid. It is set near the posterior end of the basisphenoid, whereas it is located in the centre of the ventral surface in most other ophthalmosaurids (Maxwell, 2010; VF, pers. obs.). Elongated ridges border the carotid furrow laterally. Only the posterior end of the parasphenoid is preserved. It is an elongated rod with a triangular crosssection. 

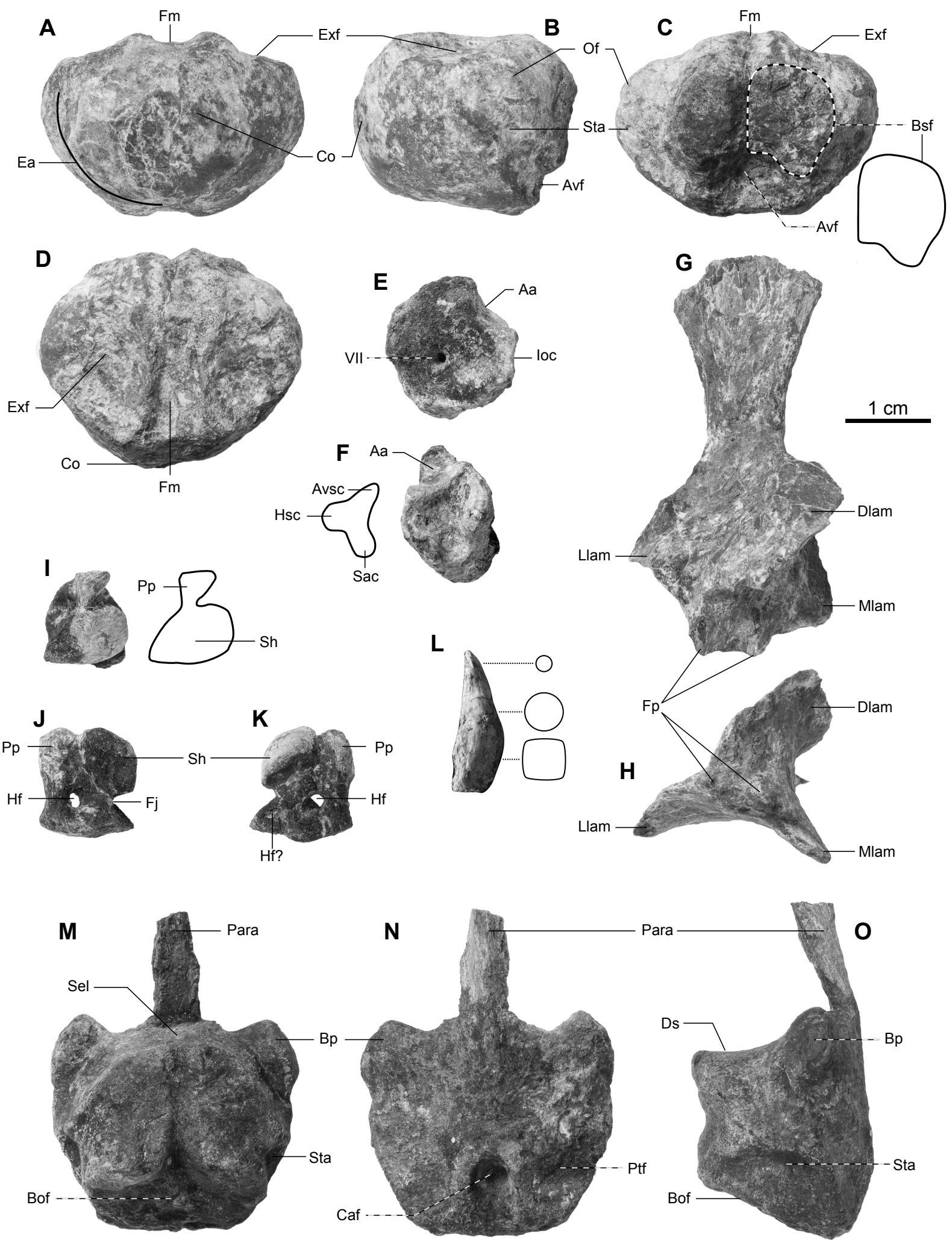

FIGURE 2. Basicranium, tooth, and palatal elements of Sveltonectes insolitus (IRSNB R269). A, basioccipital in posterior view. B, basioccipital in lateral view. C, basioccipital in anterior view and outline of the basisphenoid facet. D, basioccipital in dorsal view. $\mathbf{E}$, left prootic in lateral view. F, left prootic in posterior view and outline of the impression of the otic capsule. G, left pterygoid in dorsal view. $\mathbf{H}$, left pterygoid in posterior view. I, right exoccipital in dorsal view. $\mathbf{J}$, right exoccipital in lateral view. $\mathbf{K}$, right exoccipital in medial view. $\mathbf{L}$, tooth and its cross-sections. $\mathbf{M}$, basisphenoid in dorsal view. $\mathbf{N}$, basisphenoid in ventral view. $\mathbf{O}$, basisphenoid in lateral view. Abbreviations: Aa, area for articulation with unknown tissue; Avf, anteroventral fossa; Avsc, impression of the 
anterior verticular semi-circular canal; Bof, basioccipital facet; Bp, basipterygoid process; Bsf, outline of the basisphenoid facet; Caf, carotid furrow; Co, condyle; Dlam, dorsal lamella; Ds, dorsum sellae; Ea, limit between the condylar and the extracondylar area; Exf, exoccipital facet; $\mathbf{F j}$, foramina jugularis; $\mathbf{F m}$, foramen magnum; $\mathbf{F p}$, forked process; Hf, hypoglossal foramen; Hsc, impression of the horizontal semi-circular canal; Ioc, impression of the otic capsule; Llam, lateral lamella; Mlam, medial lamella; Of, opisthotic facet; Para, parasphenoid; Pp, posterior pillar process; Ptf, facet for medial lamella of the pterygoid; Sac, impression of the sacculus and/or the utriculus; Sel, sella turcica; Sh, supraoccipital head; Sta, stapedial facet; VII, facialis nerve (cranial nerve VII).

Basioccipital-The basioccipital is slightly compressed dorsoventrally. It bears a large, hemispherical condyle with an irregular surface. The dorsal surface of the basioccipital is flat (Fig. 2B), as in Brachypterygius (McGowan and Motani, 2003), Arthropterygius (Maxwell, 2010), and P. australis (Kear, 2005). The foramen magnum forms a median groove that separates the elliptical exoccipital facets. There is a deep median incision on the anterior edge of the dorsal surface in the prolongation of the foramen magnum. This incision extends on the anterior surface and abuts in a deep ovoid anteroventral excavation (Fig. 2C). Dorsal to this pit, the median incision is bordered laterally by paired ovoid and rugose articular protuberances for the basisphenoid (Fig. 2C). The extracondylar area is extremely reduced (Fig. 2A, B), as in Arthropterygius, Brachypterygius, and Platypterygius (McGowan and Motani, 2003; Maxwell, 2010). Dorsally, the oblique stapedial facet contacts the elevated and flattopped opisthotic facet.

Exoccipital-The anterior process at the base of the exoccipital is strongly reduced in comparison to most ophthalmosaurids such as Mollesaurus, Ophthalmosaurus, Brachypterygius, and Platypterygius (McGowan, 1976; Kirton, 1983; Fernández, 1999; Kear, 2005). The ventral surface is superficially heart-shaped. The shaft of the exoccipital is perforated by one large hypoglossal foramen as in Mollesaurus (Fernández, 1999). A second hypoglossal foramen is possibly present, but seems strongly reduced (Fig. 2K). However, the number of foramina appears to be variable amongst Ophthalmosauridae, as shown by Maisch (1997) for Ophthalmosaurus. Dorsally, a dorsoventrallyoriented groove separates the supraoccipital head from a posterior pillar-shaped process (Fig. 2I, K), a unique condition in ichthyosaurs.

Prootic - The left prootic is roughly hexagonal in lateral view and laterally compressed. Its anterior lamella slightly bends laterally. Just below the mid-point, this lamella is perforated by a cylindrical, mediolateral foramen (Fig. 2E), bordered medioventrally by a curved ridge. This foramen probably housed facial nerve (cranial nerve VII) as in other reptiles, including the Triassic ichthyosaur Mixosaurus (Maisch et al., 2006). This is the first time that a prootic foramen is reported in post-Triassic ichthyosaurs. The posterior surface of the prootic is roughly triangular and bears a deep, tri-radiate impression of the anterior part of the otic capsule. The impression of the horizontal semi-circular canal forms the widest branch and the impression of the anterior vertical semi-circular canal forms the narrowest and shallowest branch. Unusually, the ventral part of the otic impression houses a single tearshaped impression for the sacculus and/or utriculus. In other ophthalmosaurids, the ventral part of the otic impression is wide, with separated impressions for the sacculus, the utriculus, and the ampulla (e.g., Andrews, 1910; Kirton, 1983; Kear, 2005). The posterior surface is bordered ventrally by a large and rugose bulge and dorsally by a triangular and concave surface (Fig. 2E, F), which may be an articular facet or an attachment area for muscle or cartilage.

\section{Mandible}

Dentary - The dentary closely resembles the premaxilla. A deep, narrow, and continuous fossa dentalis extends along its lateral side and reaches the level of the anterior border of the orbit. Posteriorly, the fossa dentalis forms a broader but shallower sulcus that extends on to the surangular. 
Splenial - Both splenials are incompletely preserved and partly disarticulated (Fig. 1). In ventral view, the anterior end of the splenials is situated $15 \mathrm{~cm}$ from the tip of the mandible.

Angular - The angular has a high, S-shaped posterior end. As in all ophthalmosaurids (Maisch and Matzke, 2000b), the angular is markedly exposed laterally, although less than in O. icenicus (Kirton, 1983) and Athabascasaurus (Druckenmiller and Maxwell, 2010). Its lateral and medial surfaces are weakly concave.

Surangular-The surangular is superficially S-shaped. Its lateral surface is concave in extension of the fossa dentalis. Unlike in other Ophthalmosauridae (e.g., Kirton, 1983), the lateral surface of the surangular is flat and lacks a fossa surangularis.

Articular - Both articulars are disarticulated. The medial surface for the quadrate is saddle-shaped and it bears a small, dorsoventrally-elongated bulge that possibly marks the insertion of a $\mathrm{M}$. adductor mandibulae internus pterygoideus posterior (Kear, 2005). The ventrolateral surface is ovoid, concave, and slightly rugose. A prominent, flat-topped ridge separates these surfaces medially.

Hyoid - Both hyoids lie over the splenials and the right part of the mandible (Fig. 1A, C). They are rod-like and slightly curved. The anterior end is convex, smooth, and laterally compressed. Posteriorly, it becomes rounded in cross-section, the opposite condition of $P$. australis and P. hercynicus (Kear, 2005; Kolb and Sander, 2009).

\section{Dentition}

Thirty-four teeth are preserved. They are very small: the largest tooth measures $19 \mathrm{~mm}$ in total height and the tooth length index (TLI, sensu McGowan, 1976) is 0.11, which is about half that of typical toothed post-Liassic ichthyosaurs such as Platypterygius or Brachypterygius, but slightly larger than those of Aegirosaurus (Maisch and Matzke, 2000b; Fischer et al., 2011). About half of the teeth are recurved. All have a sharply pointed apex. The crown is circular in cross-section and restricted to the upper third of the tooth (Fig. 2L). The crown is ornamented by delicate longitudinal striations. The root progressively becomes squared in cross-section towards its base, as in Brachypterygius, Platypterygius, Maiaspondylus, and Undorosaurus (Bardet, 1990; Efimov, 1999; Maxwell and Caldwell, 2006b; VF, pers. obs.) and bears subtle longitudinal striations.

\section{Axial Skeleton}

Centra-A discontinuous series of 76 centra is preserved. The different regions of the vertebral column are poorly defined in ichthyosaurs because the pectoral and pelvic girdles are not connected to the axial skeleton. For descriptive purposes only, it is commonly accepted that in Thunnosauria the cervical centra have diapophyses fused to the facet for the neural arch, the anterior dorsal centra have separated diapophyses and parapophyses on the upper half of the centrum, the posterior dorsal centra have separated diapophyses and parapophyses located in lower half of the centrum, the anterior caudal centra have a single, lateroventrally-oriented apophysis, and that apical and postflexural centra are usually laterally compressed and bear chevron facets ventrally (McGowan and Motani, 2003; Kolb and Sander, 2009). According to these definitions, 22 cervical centra, 6 anterior dorsals, 11 posterior dorsals, 26 anterior caudals, 2 apicals, and 11 postflexurals are preserved in IRSNB R269. The atlas-axis is missing. All centra are strongly amphicoelous and similar in proportions (Fig. 3), resulting in a very poorly regionalized vertebral column, even less than that of Ophthalmosaurus natans (Massare et al., 2006). The nine anterior-most cervical centra are small and heart-shaped, with a prominent ventral keel. This ridge progressively disappears on posterior centra as the ventral surface of the centra becomes rounded. In the cervical region, the neural canal region is frequently slightly concavo-convex in the transverse plane. This probably helped to straighten that part of the vertebral column. Thoracic and anterior caudal centra are rounded. The anterior surface of apical centra is bulged, resulting in a ball-ina-socket articulation. The only complete apical centrum preserved accounts alone for $2.9^{\circ}$ of the tail 
bend using McGowan's (1989) trapeze method. Apicals and postflexurals lack chevron facets. Postflexurals are dorsoventrally and anteroposteriorly elongated, although less than in Platypterygius platydactylus (Broili, 1907).

The unusually high number of so-called cervical centra is interpreted as a retention of the neural facet-diapophysis contact up the middle thoracic region, and therefore does not indicate a particularly long neck. This condition is also found in "Otschevia" alekseevi (22; Arkhangelsky, 2001) and Platypterygius americanus (18; Maxwell and Kear, 2010).

Neural Arches-Thirty-eight complete or subcomplete neural arches are disarticulated. However, a series of eight neural arches can be identified as cervical, because their columnar pedicles perfectly articulates with the small and rounded facets on the dorsal surface of the cervical centra. The pedicles of the remaining neural arches are anteroposteriorly elongated. The emargination of the posterior edge of the neural spine is much deeper in the cervical region, each neural arch being tightly locked to the preceding one. The emargination becomes shallower or absent on posterior neural spines. Like in $P$. hercynicus, pre- and postzygapophyses remain separated anteriorly, in the cervical and anterior dorsal regions, and are usually completely fused in the posterior dorsal and anterior caudal regions (Kolb and Sander, 2009). They disappear in the postflexural region.

Ribs-Many rib fragments are preserved, but no rib is complete. Two shallow grooves run along the proximal portion of the ribs, resulting in an 8-shaped cross-section. Theses grooves vanish distally and the ribs progressively acquire an oval then a rounded cross-section.

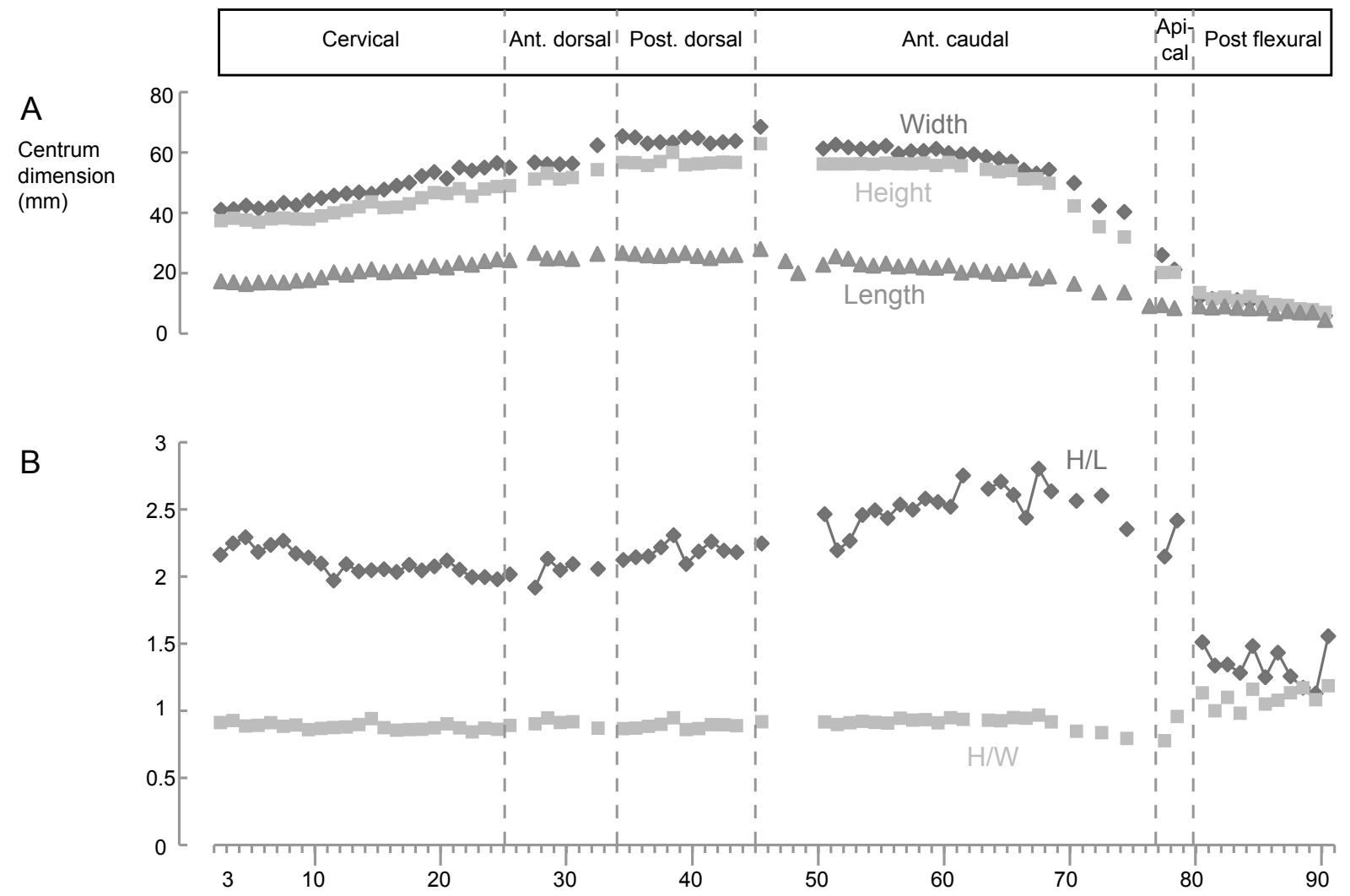

FIGURE 3. Vertebral dimensions of Sveltonectes insolitus (IRSNB R269). A, measurements. B, height/length and height/width ratios, showing the poor regionalization of the vertebral column of $S$. insolitus. The X-axis refers to the number of the centrum, not its actual position within the vertebral column. Each obvious gap in the vertebral column is represented by a single void. 


\section{Pectoral Girdle}

Coracoid - The coracoid is massive, fan-shaped, and markedly saddle-shaped ventrally (Fig. 4E, F), unlike the oval and flattened coracoid of Platypterygius (Kolb and Sander, 2009; Zammit et al., 2010; VF, pers. obs.). Like in P. australis, the intercoracoidal facet is strongly thickened, rugose, and eyeshaped in medial view (Wade, 1984). Both coracoids perfectly articulate with each other, the intercoracoidal suture being sinusoidal dorsally. Unlike in Ophthalmosaurus (Appleby, 1956), the glenoid and the scapular facet are well demarked, forming a $100^{\circ}$ angle (Fig. 5E). The anterior and posterior margins of the coracoid are thin and convex. The anterior notch is deep and narrow.

Scapula - The scapula is laterally compressed and superficially S-shaped, thus differing from the thick and rod-like scapular blade of some European specimens of Platypterygius (Kolb and Sander, 2009; VF, pers. obs.), but similar to that of P. americanus (Nace, 1939). Its dorsal end is slightly expanded, dorsally bended, and concavo-convex, following the shape of the ribcage. Anteromedially, the scapula forms a prominent acromion process (Fig. 4A, B, C). Unlike in Stenopterygius (Johnson, 1979), the acromion process does not contact the coracoid. The acromion is also clearly separated from the coracoid facet, unlike in most specimens of Ophthalmosaurus (Gilmore, 1905, 1906; Appleby, 1956; Kirton, 1983). The acromion process appears separated from the coracoid facet in Caypullisaurus (Fernández, 1997), although this region is poorly known in this taxon. Dorsolaterally, the acromion process forms a large, thin, S-shaped, flange with a rectangular outline (Fig. 4, A, B, C). The glenoid contribution of the scapula is reduced, as in O. icenicus (Andrews, 1910) and P. americanus (Nace, 1939, 1941).

Interclavicle - The anterior transverse bar of the interclavicle is slightly convex and its lateral extremities extend posterodorsally. They are separated at the midline by an oblique fracture, interpreted as an unhealed fracture, because it extends on the anterior part of the ventral surface of the interclavicle, but is absent on the dorsal (internal) surface. The posterior median stem is an elongated process with a U-shaped cross-section. Its internal surface is markedly concave except at its base, where it has a rounded cross-section. The median stem forms numerous root-like ridges at its junction with the anterior transverse bar. 
A
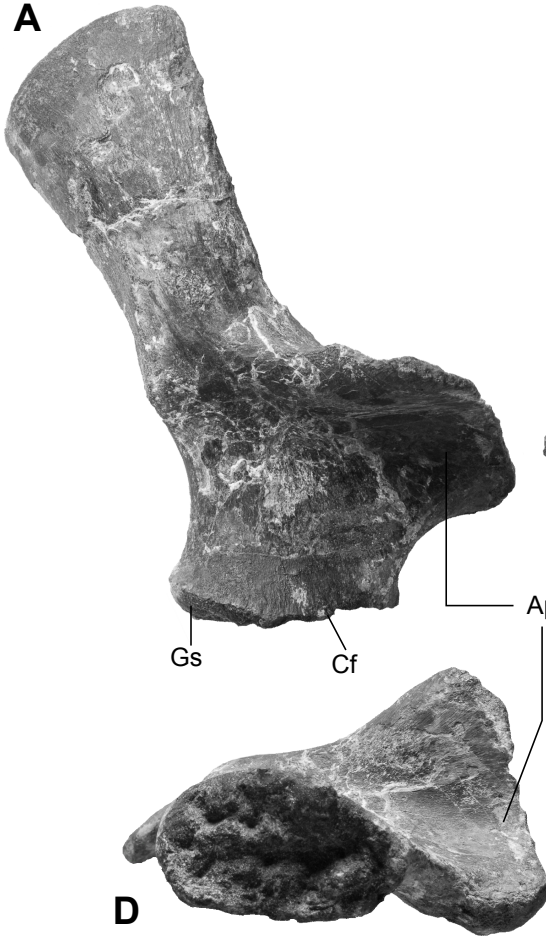

G

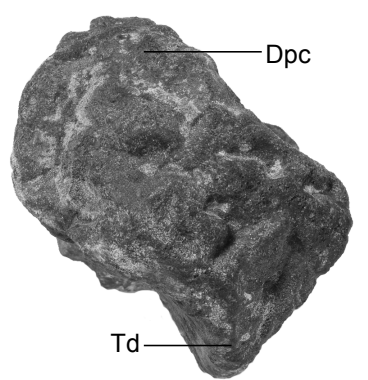

H

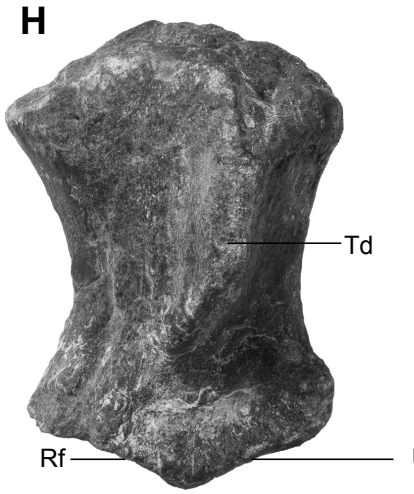

Uf

\section{B}
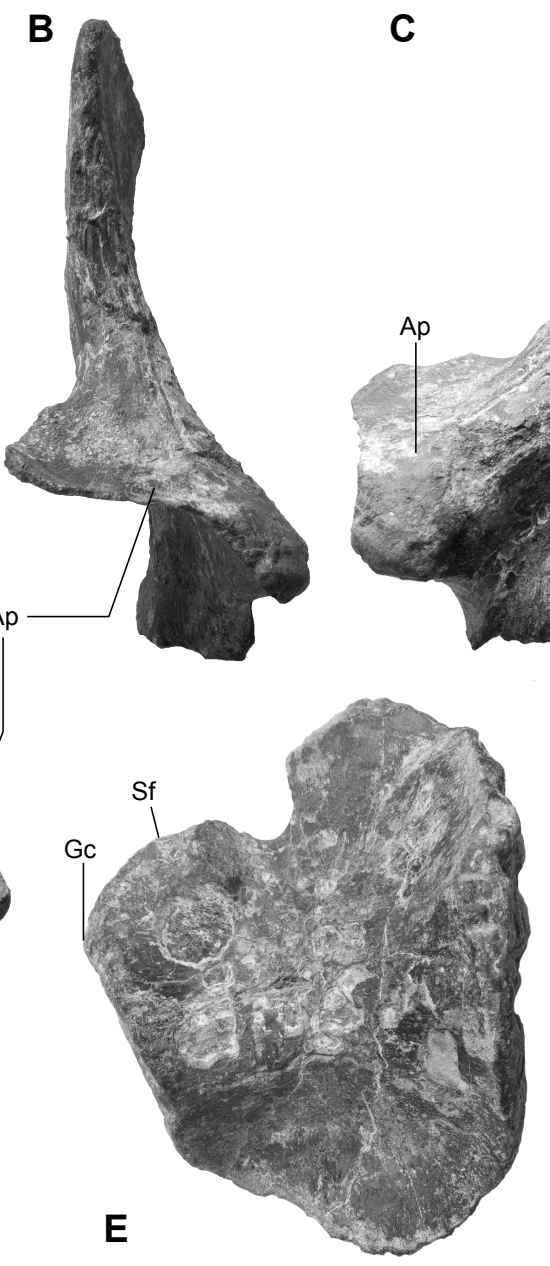
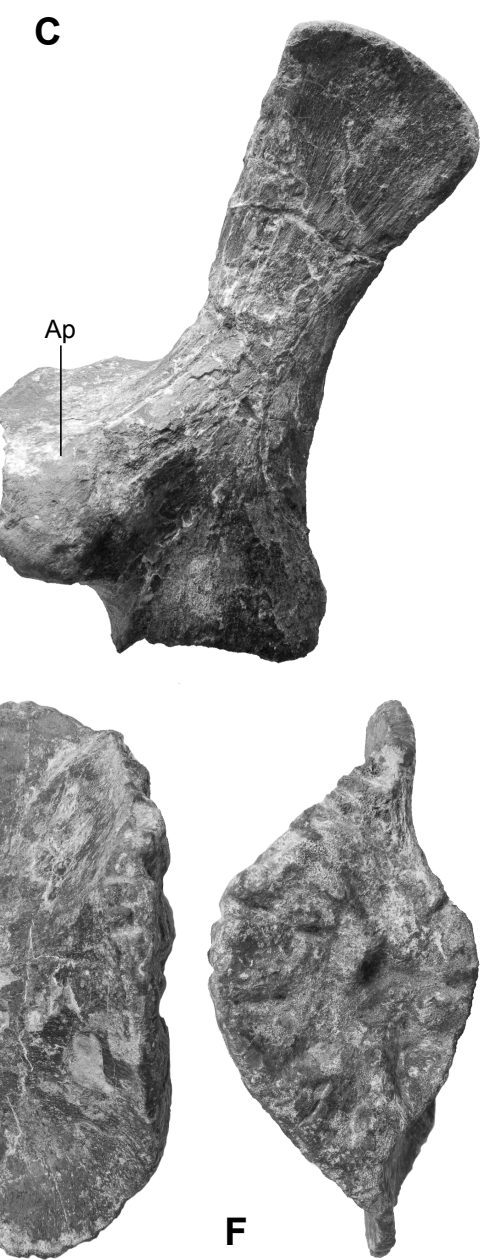

$2 \mathrm{~cm}$

$\mathbf{J}$
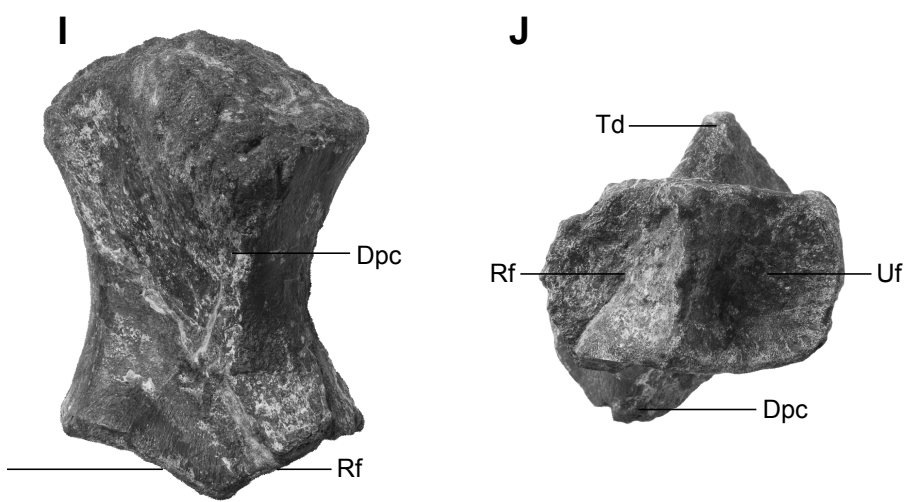

FIGURE 4. Anterior appendicular elements of Sveltonectes insolitus (IRSNB R269). A, right scapula in lateroventral view. B, right scapula in anterior view. $\mathbf{C}$, right scapula in dorsomedial view. $\mathbf{D}$, right scapula in proximal view. $\mathbf{E}$, right coracoid in ventral view. $\mathbf{F}$, right coracoid in medial view. $\mathbf{G}$, left humerus in proximal view. $\mathbf{H}$, left humerus in dorsal view. I, left humerus in ventral view. $\mathbf{J}$, left humerus in distal view. Abbreviations: Ap, acromion process; Cf, coracoidal facet; Dpc, deltopectoral crest; $\mathbf{G c}$ : glenoid contribution of the coracoid; Gs, glenoid contribution of the scapula; Rf, radial facet; $\mathbf{S f}$, scapular facet; Td, trochanter dorsalis; Uf, ulnar facet. 

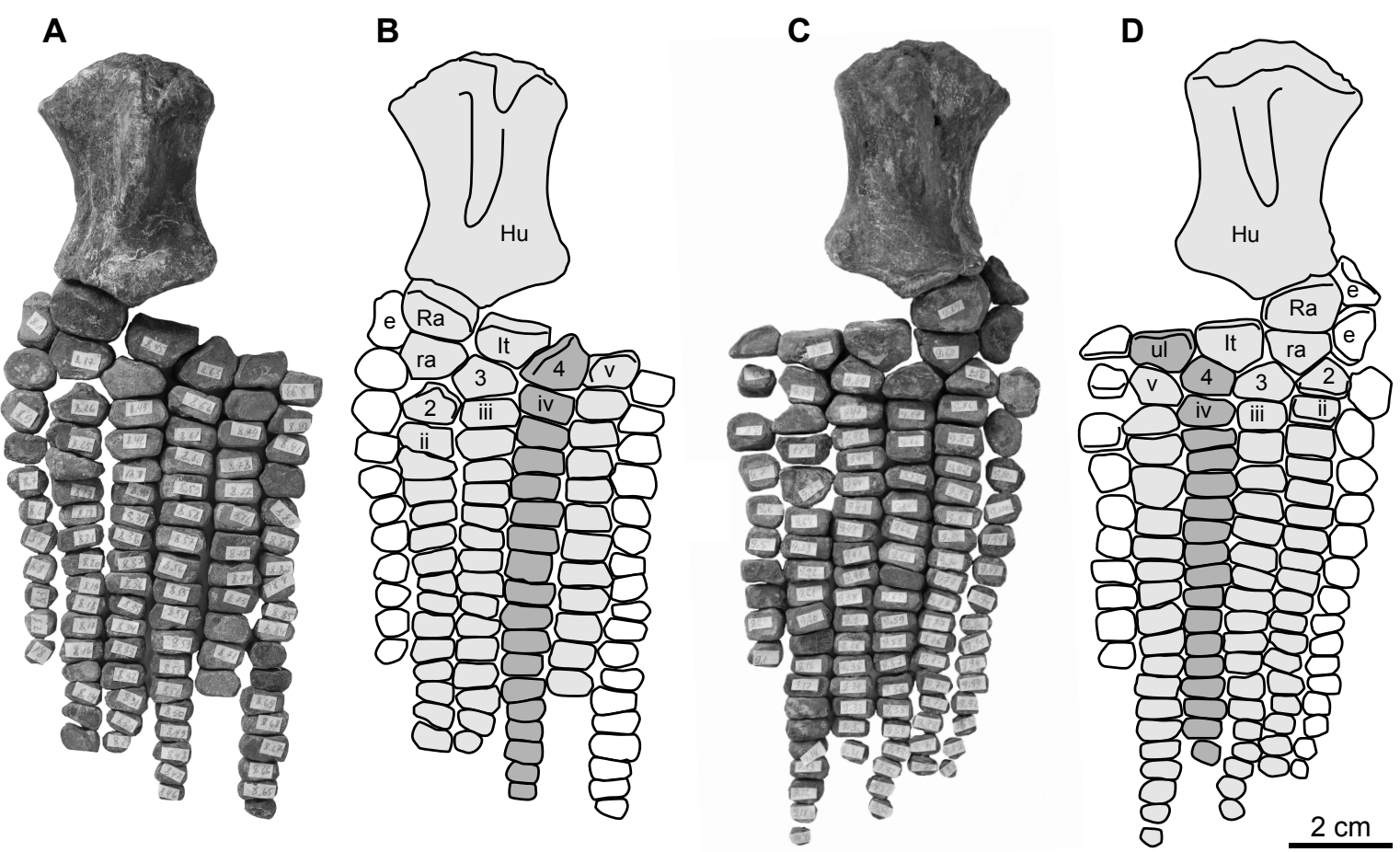

FIGURE 5. Forefins of Sveltonectes insolitus (IRSNB R269) in dorsal view. A, B, left forefin. C, D, right forefin. The primary axis of the fin is colored in dark gray and the accessory digits in white. Abbreviations: e, anterior accessory zeugopodial element; Hu, humerus; It, intermedium; Ra, radius; ra, radiale; ul, ulnare; 2-4, distal

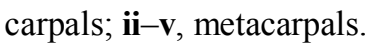

\section{Forefin}

Both forefins were found in articulation during excavation. However, about 26 displaced elements have also been unearthed, suggesting that the phalangeal count and/or the number of digits proposed here are underestimated.

Humerus - The humerus is robust, with a strongly expanded proximal half. The proximal head is slightly flattened, markedly rugose and roughly rectangular in cross-section (Fig. 4G). Both the narrow trochanter dorsalis and the wider deltopectoral crest are strongly developed (Fig. 4H, I), resembling those described in some specimens of Platypterygius (e.g., McGowan, 1972; Wade, 1990; McGowan and Motani, 2003; Kolb and Sander, 2009). Distally, the humerus has two deep and rugose distal facets for the radius and the ulna, and lacks any supplementary facets for anterior or posterior accessory elements, as in Nannopterygius and Platypterygius campylodon (Hulke, 1871; Kiprijanoff, 1881). The ulnar facet is the largest and is quadrangular in shape (Fig. 4J).

Zeugopodium - The zeugopodium is represented by both radii and one anterior extrazeugopodial element. The stout radius narrows anteriorly and distally. With the exception of its dorsal and ventral surfaces, it is rugose. Its proximal surface is convex, whereas the other surfaces are either flat or weakly concave. The right radius does not contact the intermedium, whereas the left radius and intermedium contact each other over a short distance (Fig. 5). The radius articulates anteriorly with two crescentic extrazeugopodial elements.

Basipodium - The radiale, the intermedium, and the ulnare are similar in size and pentagonal in shape, with a straight proximal surface (Fig. 5). Each element of the basipodium supports two digits distally, as in Ichthyosaurus and some specimens of Ophthalmosaurus (e.g., Kirton, 1983; McGowan and Motani, 2003), although none of these elements is diamond-shaped in IRSNB R269. The radiale articulates with the second crescentic preaxial element. 
Digits - The manus is composed of four primary digits that directly articulate with the basipodium, one preaxial accessory digit, and one postaxial accessory digit. Elements of the primary digits are rectangular to polygonal in shape and form a tightly packed mosaic similar to that of Platypterygius (e.g., Broili, 1907; Wade, 1984). Like in Platypterygius (Maisch and Matzke, 2000b), most elements are dorsoventrally thicker than proximodistally wide. Distal elements of the primary digits and most pre- and postaxial accessory digit elements are rounded. The highest phalangeal count is 19 . The very small size and rounded shape of most terminal phalanges suggest that the forefins, as preserved, are nearly complete.

\section{Pelvic Girdle}

Only one ischiopubis is preserved. Like in some other derived ophthalmosaurids (Aegirosaurus, Caypullisaurus, Athabascasaurus, and P. australis), it lacks an obturator foramen (Fig. 6, E) (Bardet and Fernández, 2000; Druckenmiller and Maxwell, 2010; Zammit et al., 2010). It is rod-like with slightly expanded extremities. The shaft is tear-drop-shaped in cross-section. Its distal end is strongly compressed laterally, whereas its proximal end forms a thickened and ovoid articular facet with rugose texture (Fig. 6F). This surface is truncated anteriorly by an anterolateral facet inclined anterolaterally.
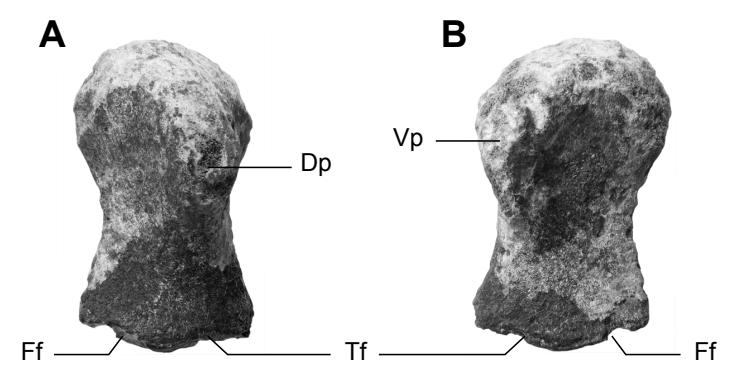

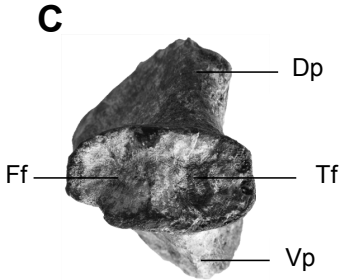

E
D

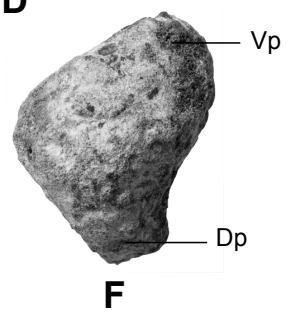

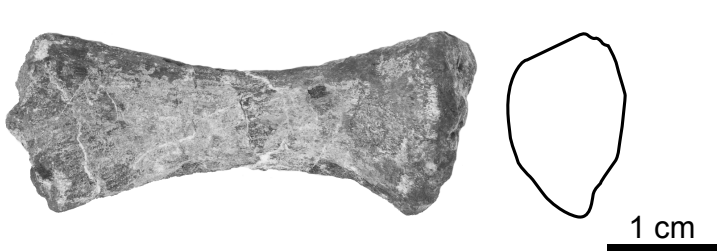

FIGURE 6. Posterior appendicular elements of Sveltonectes insolitus (IRSNB R269). A, right femur in dorsal view. B, right femur in ventral view. $\mathbf{C}$, right femur in distal view. D, right femur in proximal view. E, ?left ischiopubis in ? lateral view. F, outline of the proximal end of the ischiopubis. Abbreviations: Dp, dorsal process; $\mathbf{F f}$, fibular facet; $\mathbf{T f}$, tibial facet; $\mathbf{V} \mathbf{p}$, ventral process.

\section{Hindfin}

Femur-According to Maxwell (2010) and Maxwell and Kear (2010), we follow the orientation of the femur proposed by McGowan and Motani (2003) for Ichthyosaurus (contra the orientation proposed by Andrews [1910] and McGowan and Motani [2003] for Ophthalmosaurus). Both femora are preserved. The femur resembles the humerus in having an expanded proximal head and two distal facets. 
It is, however, about half the size of the humerus. In proximal view, the femur has a triangular outline (Fig. 6D). The femoral dorsal trochanter is oblique, high, and narrow (Fig. 6A), and the thicker and not flat-topped ventral process lies close to the anterior border of the femur (Fig. 6B). Both these processes progressively decrease in height from mid-shaft. They are separated posteriorly by a sharp edge, which is the continuation of the right-angled corner of the femoral head, and anteriorly by a large and slightly concave triangular area. The two distal facets (for the tibia and the fibula) have the same size and are markedly concave (Fig. 6C).

Distal Hindfin-Despite the slight disarticulation of the proximal rows of both hindfins, most elements of the zeugo- and basipodium can be identified (Fig. 7). Unlike in most other thunnosaurians, the hindfin is not reduced: five digits, containing up to 12 elements, are present. Only the closely related Aegirosaurus possess a comparable phalangeal count (Fernández, 2007). As in P. australis (Zammit et al., 2010), an anterior accessory element is present (Fig. 7A, C). However, Sveltonectes is unique in having four elements in the zeugopodial row of the hindfin. The anterior accessory element is pentagonal and the posterior accessory element is wedge-shaped. There are three primary digits, one preaxial accessory digit, and one postaxial accessory digit. Elements of the primary digits are brick-like, similar to those of the forefin and become rounder distally. Accessory digit elements are rounded in shape.
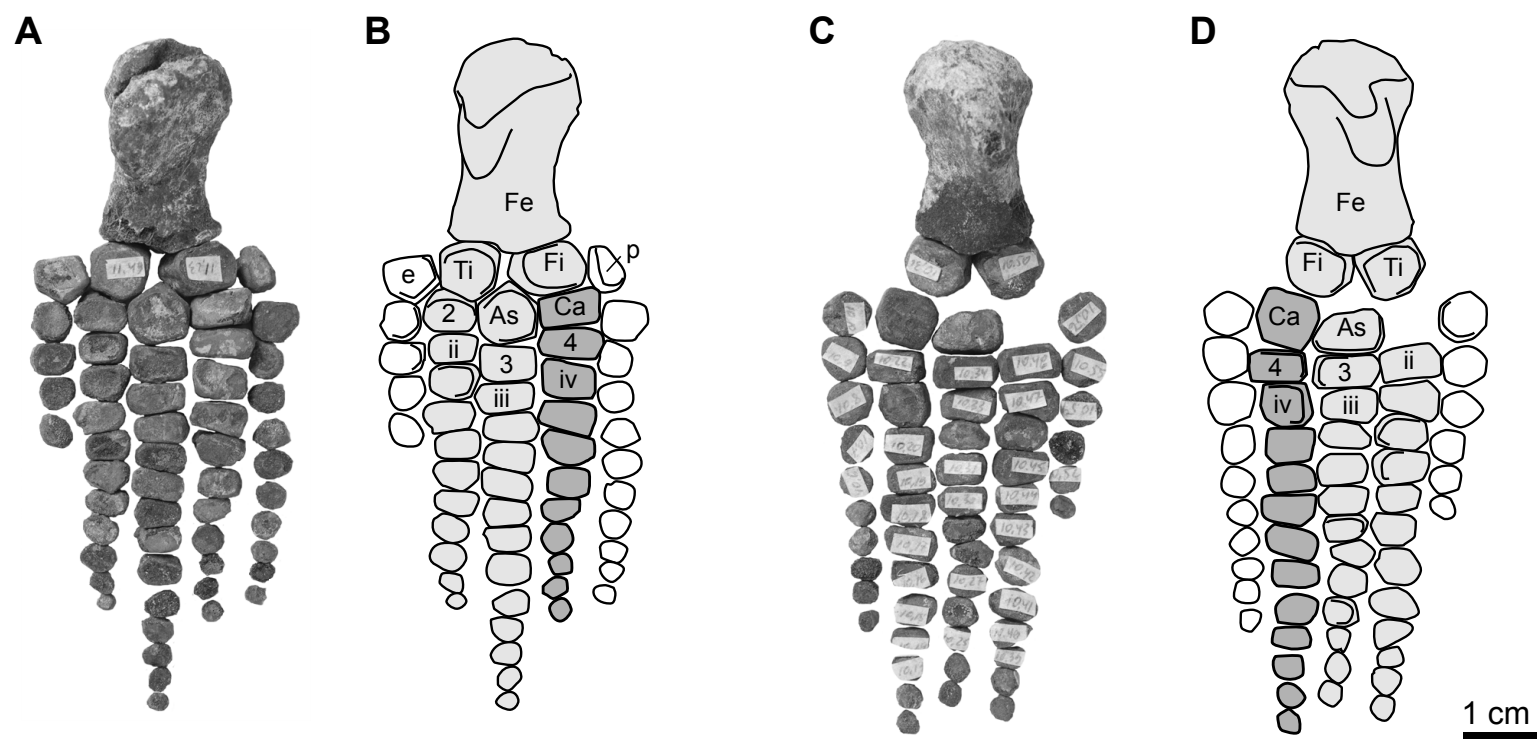

FIGURE 7. Hindfins of Sveltonectes insolitus (IRSNB R269) in dorsal view. A, B, left hindfin. C, D, right hindfin. The primary axis of the fin is colored in dark gray and the accessory digits in white. Abbreviations: As, astragalus; $\mathbf{C a}$, calcaneum; e, anterior accessory zeugopodial element; $\mathbf{F e}$, femur; $\mathbf{F i}$, fibula; $\mathbf{p}$, posterior accessory zeugopodial element; Ti, tibia; 2-4, distal tarsals. ii-iv, metatarsals.

\section{PHYLOGENETIC ANALYSIS}

\section{Methodology}

We conducted a new phylogenetic analysis of Thunnosauria (the last common ancestor of Stenopterygius quadriscissus and Ichthyosaurus communis plus all its descendants: Motani, 1999) based on 15 taxa and 50 characters (see Appendix 1 for the character list and Appendix 2 for the character matrix). Thirty-three characters are modified from literature (Godefroit, 1993; Motani, 1999; Maisch and Matzke, 2000b; Sander, 2000; Fernández, 2007; Maxwell, 2010) and 17 characters are new. Characters were coded from the literature and personal observations for Temnodontosaurus (IRSNB R122 and IRSNB R123), Stenopterygius (IRSNB R124 and IRSNB R125), Aegirosaurus (RGHP LA 
1), P. hercynicus (MHNH 2010.4 and a cast of the holotype held at the SNHM) and Sveltonectes (IRSNB R269). Characters were not weighted and, except for characters 19, 38, and 44, were not ordered.

All currently valid thunnosaurian genera are included in the data matrix, except Nannopterygius and Undorosaurus, which are too incompletely described. The genus Chacaicosaurus is used for the first time in a phylogenetic analysis. Because the monophyly of Ophthalmosaurus and Platypterygius has never been convincingly demonstrated, we coded the best-known ingroup species $O$. icenicus, $P$. australis, and P. hercynicus in the analysis. Temnodontosaurus, regarded by Motani (1999) as the sister taxon for Thunnosauria, is the outgroup of this analysis. The character states were coded from the species Temnodontosaurus platyodon and Temnodontosaurus trigonodon, because other species are badly defined and of doubtful generic assignment. Exact algorithms of TNT v1.1 (2010, original version: Goloboff et al., 2003) were used to analyze the character matrix (Appendix 2) and calculate the Bremer support and bootstrap values.

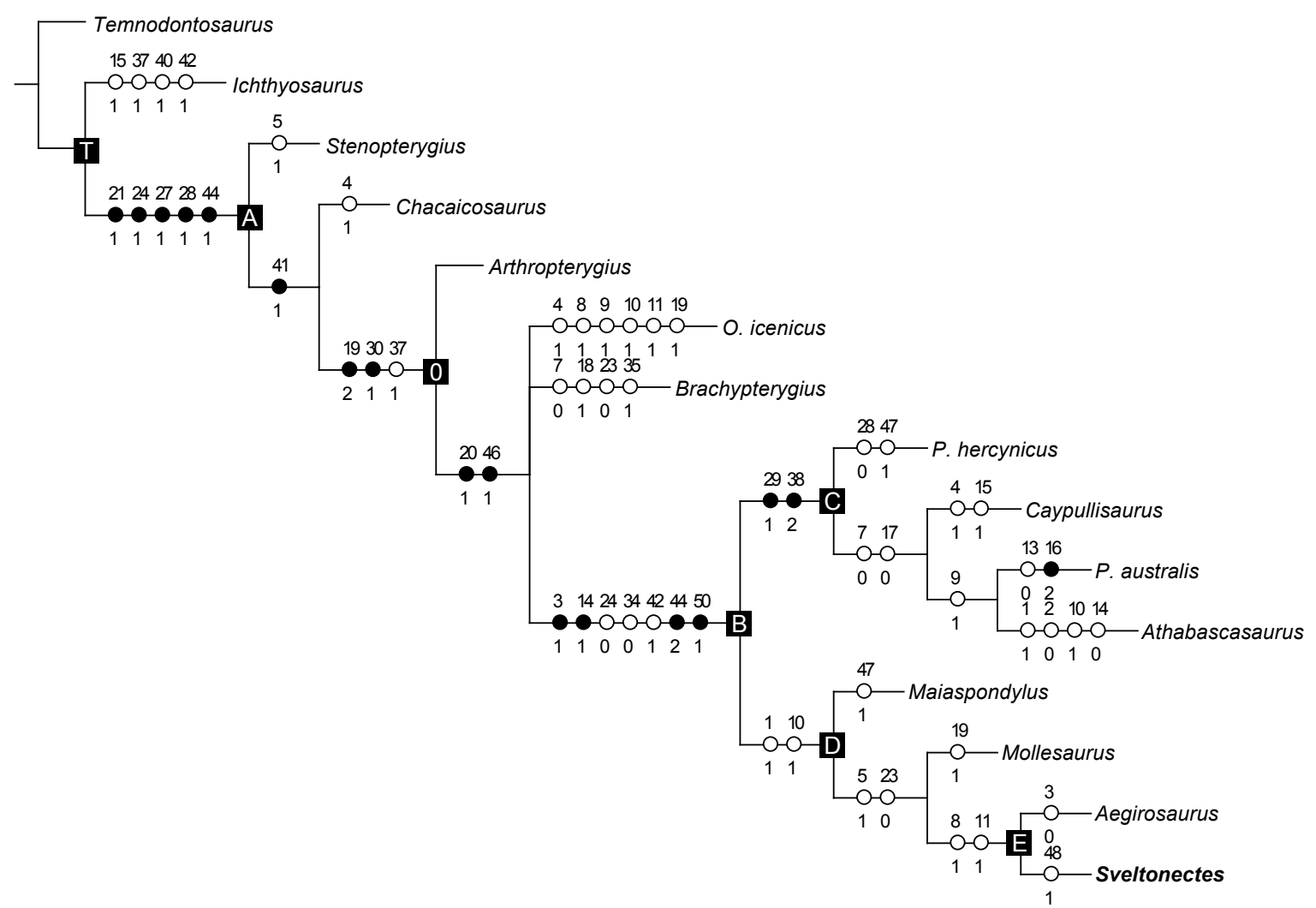

FIGURE 8. Single most parsimonious tree indicating the phylogenetic position of Sveltonectes amongst Thunnosauria. Black circles represent non-homoplasious synapomorphies, open circles homoplasious synapomorphies, and numbers above and below circles represent character number and character state, respectively. Abbreviations: T, Thunnosauria; $\mathbf{O}$, Ophthalmosauridae.

\section{Results}

Two most parsimonious trees were recovered from the analysis. The strict consensus tree (Fig. 8) has a length of 100 steps, a consistency index (CI) of 54 and a retention index (RI) of 60. These coefficients reflect a high degree of homoplasy, as already suggested in a previous analysis of ophthalmosaurid ichthyosaurs (Maxwell, 2010). The Bremer support is similarly low, being 1 at each node, except for the clade Thunnosauria (4+) and Ophthalmosauridae (3). Similarly, only the clades Thunnosauria and Ophthalmosauridae have bootstrap values above 50 (100 and 64, respectively). The clade Ophthalmosauridae as defined by Motani (1999) (the last common ancestor of Brachypterygius 
extremus and O. icenicus plus all its descendants) would not include Arthropterygius. Because this taxon shares crucial characters with Ophthalmosauridae such as the reduced extracondylar area of the basioccipital, a well-developed anterior accessory element and associated digit and a plate-like dorsal trochanter of the humerus (Maxwell, 2010), we propose here to redefine the Ophthalmosauridae as the last common ancestor of Arthropterygius chrisorum and O. icenicus plus all its descendants. The characters discussed below are non-homoplasic unless stated otherwise.

The analysis supports a Stenopterygius origin for the Ophthalmosauridae: this clade ('A') is supported by five unambiguous synapomorphies: a massive stapedial head matching that of the opisthotic in size (char. 21), anterior caudals with high height/length ratio (char. 24, reversed in clade 'B'), no chevron facets in the apical region (char. 27), a well-expressed acromion process (char. 28), and the presence of an ischiopubis (char. 44). Thick proximal elements in the paddles (char. 42) characterizes Ophthalmosauridae + Chacaicosaurus. Ophthalmosauridae are united by three unambiguous synapomorphies: the reduction of the extracondylar area of the basioccipital (char. 19), the presence of a plate-like dorsal trochanter (char. 30), and an unnotched anterior facet on elements of the leading edge of the fins (char. 38; homoplasious). The presence of an anterior accessory element articulating with the humerus (char. 34) also characterize Ophthalmosauridae, but only in fast optimization. Ophthalmosauridae without Arthropterygius are characterized by the loss of the basioccipital peg (char. 20) and the presence of well-developed dorsal and ventral trochanters on the femur (char. 46). Advanced ophthalmosaurids ('B') are united by seven unambiguous autapomorphies: a quadrangular root section (char. 3), the presence of a processus temporalis on the frontal (char. 14, reversed in Athabascasaurus), anterior caudals with low height/length ratio (char. 24, homoplasic), no posterior deflection of the ulnar facet on humerus (char. 34, homoplasic), tightly packed rectangular phalanges (char. 42, homoplasic), the lost of the obturator foramen in the ischiopubis (char. 44), and the presence of postaxial accessory digits on the hindfin (char. 50). Advanced ophthalmosaurids are divided in two clades, a 'platypterygiine' clade ('C') and a 'sveltonectine' clade ('D'). Clade 'C' is supported two autapomorphies: the absence of an anteromedial process on the coracoid (char. 29) and at least two postaxial accessory digits on the forefin (char. 38). However, the analysis failed to recover a monophyletic Platypterygius clade, suggesting that the genus Platypterygius, as currently defined, is invalid. Clade ' $\mathrm{D}$ ' is supported by two autapomorphies: the absence of crown striations (char. 1, homoplasic) and the absence of a processus supranarialis of the premaxilla (char. 10, homoplasic). Sveltonectes is united with Aegirosaurus (clade 'E') by the presence of a descending process in the external naris (char. 8; homoplasic) and the presence of a processus narialis on the prefrontal (char. 11, homoplasic).

\section{DISCUSSION}

\section{Maturity}

Johnson (1977) established four criteria on the forefin to assess the osteological maturity of the Early Jurassic genus Stenopterygius. The texture of the left humeral shaft, like fine sandpaper, and the flattened articular head of the humerus suggest that IRSNB R269 was not completely ossified when it died. Conversely, the phalanges are fully ossified and tightly packed, which indicates osteological maturity (Johnson, 1977). Fernández et al. (2005) proposed another criterion based on the relative size of the sclerotic ring: in parvipelvian ichthyosaurs, the aperture of the sclerotic ring usually equals $20 \%$ of the total surface of the orbit in juveniles, but this ratio decreases with age. Exceptions to this rule are the supposed deep divers Eurhinosaurus and Ophthalmosaurus, whose sclerotic ring aperture remains around $20 \%$ of the orbit size in adults (Fernández et al., 2005). In IRSNB R269, the sclerotic ring aperture represents $12 \%$ of the orbit size. Kear (2005) noted that the complete fusion between the parasphenoid and the basisphenoid is a potential indicator of osteological maturity in $P$. australis. This 
fusion of these bones is complete on IRSNB R269. Finally, the muscle attachment areas on the pectoral girdle are well developed, which also indicates osteological maturity in secondarily aquatic marine reptiles (Maxwell and Kear, 2010). Consequently, this specimen is considered as an adult.

\section{Ecological Diversity of Early Cretaceous Ichthyosaurs}

On the basis of tooth morphology, Massare $(1987,1997)$ defined feeding guilds amongst marine reptiles. However, most of the ichthyosaurs used in Massare's analysis were Early Jurassic in age, coming from the well-known Hettangian-Sinemurian and Toarcian anoxic shales from Europe. The incorporation of Late Jurassic to middle Cretaceous ichthyosaurs in that canvas proved to be problematic because of the appearance of intermediate or mosaic-like dental morphologies in taxa whose diet cannot be constrained by gastric contents or bromalites (Fischer et al., 2011). Furthermore, some ichthyosaurs, which were identified as belonging to the 'Grasp: smash' guild and supposedly fed on lightly armored cephalopods, were probably far more opportunistic than hypothesized by Massare: the preserved gut of a specimen of $P$. australis from the Albian of Australia contained the remains of birds, fishes, cephalopods, and small turtles (Kear et al., 2003). The ecological diversity of Cretaceous ichthyosaurs is therefore largely unknown. Sveltonectes is characterized by very small (tooth size ratio $=1.16$, see Appendix 1, character 6), delicate, and sharply-pointed teeth that contrast with those of most other Late Jurassic to Early Cretaceous ichthyosaurs, which possess large and robust teeth with a blunt apex (Brachypterygius, Platypterygius; Massare, 1987) and are grouped within the 'Grasp: smash' guild. Whereas the tooth morphology of Sveltonectes cannot be directly assigned to any of the guilds defined by Massare, it suggests the presence of a 'pierce'-oriented guild among Cretaceous ichthyosaurs, intermediate between the 'Pierce I' and 'Pierce II/General' guilds. Indeed, Massare (1987:122) indicated that a "slender shape, moderate size and a pointed apex" are general dental features effective at piercing small, soft prey. The slender snout and absence of visible tooth wear is also reminiscent of members of the Pierce I guild such as Leptonectidae, although the snout and orbital ratios of Sveltonectes are smaller than in Leptonectidae. The dental morphology of Sveltonectes would indicate a diet of small, delicate, and fleshy prey such as aulopiforme or clupeiforme fishes and soft cephalopods.

Studies on the locomotion of advanced ichthyosaurs indicate that the limbs were most likely used in stabilizing the body and maneuvering (McGowan, 1991; Buchholtz, 2001). The hindfins of Sveltonectes are long (about $2 / 3$ the size of the forefins) and wide (presence of one preaxial and one postaxial accessory digits) by ophthalmosaurid standards, and the very prominent muscle attachment areas on the scapula, the coracoid, the humerus, and the femur suggest strong, functional limbs that could have given this taxon greater maneuvering capabilities, which is in agreement with the diet deduced from the dental morphology. The vertebral column of Sveltonectes is also poorly regionalized (Fig. 4A, B), which suggests lower sustained swimming speed in favor of increased maneuverability (Massare et al., 2006). New specimens belonging a new ophthalmosaurid taxon briefly discussed by Fischer et al. (2009) indicate that a 'pierce' guild was still occupied by ichthyosaurs during the Late Albian. Interestingly, small 'pierce' and large 'smash' ichthyosaurs are commonly associated in Lower Cretaceous formations of Europe (Aptian-Albian of southeastern France: Fischer et al., 2009; Albian of England: VF, pers. obs.) and Russia (Barremian of the Ul'yanovsk region where Sveltonectes is associated to 'Ichthyosaurus' steleodon). This suggest that ichthyosaurs had a much more significant hold over the Early Cretaceous marine trophic webs than previously supposed (e.g., Bardet, 1992).

\section{CONCLUSIONS}

Sveltonectes insolitus is a new and highly derived ophthalmosaurid ichthyosaur from the late Barremian of western Russia. This taxon significantly increases the morphological and ecological diversity of Early Cretaceous ichthyosaurs, by colonizing a 'pierce'-oriented feeding guild with a 
possible diet of small, fleshy, and swift prey. Its complex osteology, combining numerous unique features and characters previously considered as autapomorphic for other taxa, confirms that the radiation of Ophthalmosauridae was rather complex, with considerable homoplasy involved, as already suggested by Maxwell (2010). This radiation took place during the Middle-Late Jurassic from a Stenopterygius-like ancestor.

\section{ACKNOWLEDGMENTS}

We sincerely thank T. Hubin (RBINS) for making the photographs, P. Golinvaux for drawing the skull, F. Escuillié for providing early access to the specimen, and both M. Giraldo Martin and E. Javaux (University of Liège, Belgium) for the palynomorph extraction and a preliminary analysis. Michael Maisch and Benjamin Kear (Uppsala University) are warmly thanked for their comments and suggestions. VF is supported by a FNRS grant (Aspirant du F.R.S.-FNRS).

\section{LITERATURE CITED}

Andrews, C. W. 1910. A descriptive catalogue of the Marine Reptiles of the Oxford Clay, part I. British Museum of Natural History, London, 205 pp.

Appleby, R. M. 1956. The osteology and taxonomy of the fossil reptile Ophthalmosaurus. Proceedings of the Zoological Society of London 126:403-447.

Arkhangelsky, M. S. 2001. On a new ichthyosaur of the genus Otschevia from the Volgian Stage of the Volga Region near Ulyanovsk. Paleontological Journal 35:629-634.

Bardet, N. 1990. Dental cross-section in Cretaceous Ichthyopterygia: systematic implications. Geobios 23:169-172.

Bardet, N. 1992. Stratigraphic evidence for the extinction of the ichthyosaurs. Terra Nova 4:649-656.

Bardet, N. 1994. Extinction events among Mesozoic marine reptiles. Historical Biology 7:313-324.

Bardet, N. 1995. Evolution et extinction des reptiles marins au cours du Mésozoïque. Palaeovertebrata 24:177-283.

Bardet, N., and M. Fernández. 2000. A new ichthyosaur from the Upper Jurassic lithographic limestones of Bavaria. Journal of Paleontology 74:503-511.

Bardet, N., S. Duffaud, M. Martin, J.-M. Mazin, X. P. Suberbiola, and J.-P. Vidier. 1997. Découverte de l'ichthyosaure Ophthalmosaurus dans le Tithonien (Jurassique supérieur) du Boulonnais, Nord de la France. Neues Jahrbuch für Geologie und Paläontologie. Abhandlungen 205:339354.

Baur, G. 1887. On the morphology and origin of the Ichthyopterygia. American Naturalist 21:837-840.

Blainville, H. M. D. de. 1835. Description de quelques espèces de reptiles de la Californie, précédée de l'analyse d'un système général d'érpetologie et d'amphibiologie. Nouvelles annales du Muséum d'Histoire naturelle, Paris 4:233-296.

Bogolubow, N. N. 1909. Sur quelques restes de deux reptiles (Cryptoclidus simbirskensis n. sp. et Ichthyosaurus steleodon n. sp.) trouvés par Mr. le Profess. P. Pavlow sur les bords de la Volga dans les couches mesozoïques de Simbirsk. Annuaire géologique et minéralogique de Russie 11:42-64.

Broili, F. 1907. Ein neüer Ichthyosaurus aus der norddeutschen Kreide. Palaeontographica 54:139-162.

Buchholtz, E. A. 2001. Swimming styles in Jurassic ichthyosaurs. Journal of Vertebrate Paleontology 21:61-73. 
Choo, B. 1999. Cretaceous ichthyosaurs from Western Australia. Records of the Western Australian Museum, Supplement 57:207-218.

Costa, L. I., and R. J. Davey. 1992. Dinoflagellate cysts of the Cretaceous System; pp. 99-153 in A. J. Powell (ed.), A Stratigraphic Index of Dinoflagellate Cysts. Chapman and Hall, London.

Dechaseaux, C. 1954. L'arrière-crâne d'un ichthyosaurien du Lias. Annales de Paléontologie 40:67-77.

Druckenmiller, P. S., and E. E. Maxwell. 2010. A new Lower Cretaceous (lower Albian) ichthyosaur genus from the Clearwater Formation, Alberta, Canada. Canadian Journal of Earth Sciences 47:1037-1053.

Efimov, V. M. 1997. A new genus of ichthyosaurs from the Late Cretaceous of the Ulyanovsk Volga region. Paleontological Journal 31:422-426.

Efimov, V. M. 1999. A new family of ichthyosaurs, the Undorosauridae fam. nov. from the Volgian stage of the European part of Russia. Paleontological Journal 33:174-181.

Fernández, M. 1994. A new long-snouted ichthyosaur from the early Bajocian of Neuquén basin (Argentina). Ameghiana 31:291-297.

Fernández, M. 1997. A new ichthyosaur from the Tithonian (Late Jurassic) of the Neuquén Basin (Argentina). Journal of Paleontology 71:479-484.

Fernández, M. 1998. Nuevo material de Caypullisaurus bonapartei Fernández (Reptilia: Ichthyosauridae) del Jurásico superior de la Cuenca Neuquina, Argentina. Ameghiniana 35:2124.

Fernández, M. 1999. A new ichthyosaur from the Los Molles Formation (Early Bajocian), Neuquén basin, Argentina. Journal of Paleontology 73:677-681.

Fernández, M. 2001. Dorsal or ventral? Homologies of the forefin of Caypullisaurus (Ichthyosauria: Ophthalmosauria). Journal of Vertebrate Paleontology 21:515-520.

Fernández, M. 2007. Redescription and phylogenetic position of Caypullisaurus (Ichthyosauria: Ophthalmosauridae). Journal of Paleontology 81:368-375.

Fernández, M., and M. B. Aguirre-Urreta. 2005. Revision of Platypterygius hauthali von Huene, 1927 (Ichthyosauria, Ophthalmosauridae) from the Early Cretaceous of Patagonia, Argentina. Journal of Vertebrate Paleontology 25:583-587.

Fernández, M., F. Archuby, M. Talevi, and R. Ebner. 2005. Ichthyosaurian eyes: paleobiological information content in the sclerotic ring of Caypullisaurus (Ichthyosauria, Ophthalmosauria). Journal of Vertebrate Paleontology 25:330-337.

Fischer, V. In press. New data on the ichthyosaur Platypterygius hercynicus and its implications for the validity of the genus. Acta Palaeontologica Polonica.

Fischer, V., M. Guiomar, and P. Godefroit. 2009. High diversity in late Early Cretaceous ichthyosaurs. Journal of Vertebrate Paleontology, SVP Program and Abstracts Book 2009:96A.

Fischer, V., A. Clément, M. Guiomar, and P. Godefroit. 2011. The first definite record of a Valanginian ichthyosaur and its implication for the evolution of post-Liassic Ichthyosauria. Cretaceous Research 32:155-163.

Fraas, E. E. 1891. Ichthyosaurier der Süddeutschen Trias und Jura-Ablagerungen. H. Laupp, Tübingen, $81 \mathrm{pp}$.

Gilmore, C. W. 1905. Osteology of Baptanodon (Marsh). Memoirs of the Carnegie Museum II:77-129.

Gilmore, C. W. 1906. Notes on osteology of Baptanodon. Memoirs of the Carnegie Museum II:325337.

Godefroit, P. 1993. The skull of Stenopterygius longifrons (Owen, 1881). Revue de Paléobiologie de Genève volume spécial 7:67-84.

Goloboff, P., J. Farris, and K. Nixon. 2003. T.N.T.: Tree Analysis Using New Technology. Available at www.zmuc.dk/public/phylogeny. Accessed June 11, 2010. 
Hulke, J. W. 1871. Note on an Ichthyosaurus (I. enthekiodon) from the Kimmeridge Bay, Dorset. Quarterly Journal of the Geological Society of London 27:440-441.

ICS. 2006. Early Cretaceous (103-138 time-slice). International Commission on Stratigraphy website. Available at http://www.stratigraphy.org. Accessed January 23, 2009.

Johnson, R. 1977. Size independent criteria for estimating relative age and the relationship among growth parameters in a group of fossil reptiles (Reptilia: Ichthyosauria). Canadian Journal of Earth Sciences 14:1916-1924.

Johnson, R. 1979. The osteology of the pectoral complex of Stenopterygius Jaekel (Reptilia: Ichthyosauria). Neues Jahrbuch für Geologie und Paläontologie, Abhandlungen 159:41-86.

Kear, B. P. 2003. Cretaceous marine reptiles of Australia: a review of taxonomy and distribution. Cretaceous Research 24:277-303.

Kear, B. P. 2005. Cranial morphology of Platypterygius longmani Wade, 1990 (Reptilia: Ichthyosauria) from the Lower Cretaceous of Australia. Zoological Journal of the Linnean Society 145:583622.

Kear, B. P., W. E. Boles, and E. T. Smith. 2003. Unusual gut contents in a Cretaceous ichthyosaur. Proceedings of the Royal Society B, Biology Letters 270:S206-S208.

Kiprijanoff, W. 1881. Studien über die Fossilen Reptilien Russlands. Theil 1 Gattung Ichthyosaurus König aus dem severischen Sandstein oder Osteolith de Kreide-Gruppe. Mémoires de l'Académie impériale des Sciences de St.-Pétersbourg, VIIe série 28:1-103.

Kirton, A. M. 1983. A review of British Upper Jurassic ichthyosaurs. Ph.D. dissertation, University of Newcastle upon Tyne, Newcastle upon Tyne, $239 \mathrm{pp}$.

Kolb, C., and P. M. Sander. 2009. Redescription of the ichthyosaur Platypterygius hercynicus (Kuhn 1946) from the Lower Cretaceous of Salzgitter (Lower Saxony, Germany). Palaeontographica Abteilung a-Palaozoologie-Stratigraphie 288:151-192.

Lingham-Soliar, T. 2003. Extinction of ichthyosaurs: a catastrophic or evolutionary paradigm? Neues Jahrbuch für Geologie und Paläontologie, Abhandlungen 228:421-452.

Maisch, M. W. 1997. Variationen im Verlauf der Gerhinnerven bei Ophthalmosaurus (Ichthyosauria, Jura). Neues Jahrbuch für Geologie und Paläontologie, Monatshefte 1997:425-433.

Maisch, M. W. 2008. Revision der Gattung Stenopterygius Jaekel, 1904 emend. von Huene, 1922 (Reptilia: Ichthyosauria) aus dem unteren Jura Westeuropas. Palaeodiversity 1:227-271.

Maisch, M. W., and A. T. Matzke. 2000a. New data on the cranial osteology of Ichthyosaurus communis Conybeare, 1822. Geologica et Palaeontologica 34:137-143.

Maisch, M. W., and A. T. Matzke. 2000b. The Ichthyosauria. Stuttgarter Beiträge zur Naturkunde: Serie B Geologie und Paläontologie 298:1-159.

Maisch, M. W., A. T. Matzke, and W. Brinkmann. 2006. The otic capsule of the Middle Triassic ichthyosaur Mixosaurus from Monte San Giorgio (Switzerland): new evidence on the braincase structure of basal ichthyosaurs. Eclogae Geologiae Helvetiae 99:205-210.

Massare, J. A. 1987. Tooth morphology and prey preference of Mesozoic marine reptiles. Journal of Vertebrate Paleontology 7:121-137.

Massare, J. A. 1997. Faunas, behavior, and evolution; pp. 401-421 in J. M. Callaway and E. L. Nicholls (eds.), Ancient Marine Reptiles. Academic Press, San Diego.

Massare, J. A., E. A. Buchholtz, J. Kenney, and A.-M. Chomat. 2006. Vertebral morphology of Ophthalmosaurus natans (Reptilia: Ichthyosauria) from the Jurassic Sundance Formation of Wyoming. Paludicola 5:242-254.

Maxwell, E. E. 2010. Generic reassignment of an ichthyosaur from the Queen Elizabeth Islands, Northwest Territories, Canada. Journal of Vertebrate Paleontology 30:403-415. 
Maxwell, E. E., and M. W. Caldwell. 2006a. Evidence for a second species of the ichthyosaur Platypterygius in North America: a new record from the Loon River Formation (Lower Cretaceous) of northwestern Canada. Canadian Journal of Earth Sciences 43:1291-1295.

Maxwell, E. E., and M. W. Caldwell. 2006b. A new genus of ichthyosaur from the Lower Cretaceous of Western Canada. Palaeontology 49:1043-1052.

Maxwell, E. E., and B. P. Kear. 2010. Postcranial anatomy of Platypterygius americanus (Reptilia: Ichthyosauria) from the Cretaceous of Wyoming. Journal of Vertebrate Paleontology 30:1059_ 1068 .

Mazin, J.-M. 1982. Affinités et phylogénie des Ichthyopterygia. Geobios, mémoire spécial 6:85-98.

McGowan, C. 1972. The systematics of Cretaceous ichthyosaurs with particuliar reference to the material from North America. Contributions to Geology 11:9-29.

McGowan, C. 1973. The cranial morphology of the Lower Liassic latipinnate ichthyosaurs of England. Bulletin of the British Museum (Natural History) Geology 24:1-109.

McGowan, C. 1976. The description and phenetic relationships of a new ichthyosaur genus from the Upper Jurassic of England. Canadian Journal of Earth Sciences 13:668-683.

McGowan, C. 1989. Computed tomography reveals further details of Excalibosaurus, a putative ancestor for the swordfish-like ichthyosaur Eurhinosaurus. Journal of Vertebrate Paleontology 9:269-281.

McGowan, C. 1991. Dinosaurs, Spitfires, and Sea Dragons. Harvard University Press, 365 pp.

McGowan, C., and R. Motani. 2003. Ichthyopterygia; in H.-D. Sues (ed.), Handbook of Paleoherpetology, Part 8. Verlag Dr. Friedrich Pfeil, München, 175 pp.

Motani, R. 1999. Phylogeny of the Ichthyopterygia. Journal of Vertebrate Paleontology 19:473-496.

Motani, R. 2005. Evolution of fish-shaped reptiles (Reptilia: Ichthyopterygia) in their physical environments and constraints. Annual Review of Earth and Planetary Sciences 33:395-420.

Nace, R. L. 1939. A new ichthyosaur from the Upper Cretaceous Mowry Formation of Wyoming. American Journal of Science 237:673-686.

Nace, R. L. 1941. A new ichthyosaur from the Late Cretaceous of northeastern Wyoming. American Journal of Science 239:908-914.

Owen, R. 1840. Report on British fossil reptiles. Reports of the British Association for the Advancement of Science 9:43-126.

Paramo, M. E. 1997. Platypterygius sachicarum (Reptilia, Ichthyosauria) nueva especie del Cretácio de Colombia. Revista Ingeominas 6:1-12.

Sander, P. M. 2000. Ichthyosauria: their diversity, distribution, and phylogeny. Paläontologische Zeitschrift 74:1-35.

Sirotti, A., and C. Papazzoni. 2002. On the Cretaceous ichthyosaur remains from the Northern Apennines (Italy). Bollettino della Societa Paleontologica Italiana 41:237-248.

Wade, M. 1984. Platypterygius australis, an Australian Cretaceous ichthyosaur. Lethaia 17:99-113.

Wade, M. 1990. A review of the Australian Cretaceous longipinnate ichthyosaur Platypterygius (Ichthyosauria, Ichthyopterygia). Memoirs of the Queensland Museum 28:115-137.

Zammit, M., R. M. Norris, and B. P. Kear. 2010. The Australian Cretaceous ichthyosaur Platypterygius australis: a description and review of postcranial remains. Journal of Vertebrate Paleontology 30:1726-1735. 
APPENDIX 1. Description of characters used in phylogenetic analysis. Characters are polarized with respect to Temnodontosaurus as the outgroup. New characters are indicated by an asterisk (*).

\section{Skull}

1. Crown striation: presence of deep longitudinal ridges (0); crown enamel subtly ridged or smooth (1) (Druckenmiller and Maxwell, 2010:character 25).

2. *Base of the enamel layer: poorly defined, invisible (0); well defined, precise (1).

3. *Root cross-section: rounded (0); quadrangular (1).

4. Complete, well-developed dentition retained in adults (0); adult completely or nearly edentulous (1) (Maisch and Matzke, 2000b:character 4).

5. Tooth size relative to basioccipital width: large $(\geq 3)(0)$; small $(\leq 1.5)(1)$. Derived from character 39 of Motani (1999). The tooth size relative to basioccipital width (Tooth size ratio [TSR] = $10 *$ largest crown height/basioccipital width) is a new ratio that is easy to obtain even in fragmentary specimens and that still maintains an ecological significance (basioccipital width is well correlated to skull width/'gullet size' in ichthyosaurs $\left[\mathrm{R}^{2}=0.88\right.$; VF unpublished data]). Sveltonectes and Mollesaurus have very reduced TSR (1.16 and $\approx 1.12$, respectively), whereas other ichthyosaurs such as Brachypterygius and Platypterygius have much larger teeth (TSR in between 2.96 and 4.88).

6. Processus postpalatinis pterygoidei: absent (0); present (1). (Maisch and Matzke, 2000b:character $38)$.

7. *Maxilla anterior process: extending anteriorly as far as nasal or further anteriorly (0); reduced (1).

8. Descending process of the nasal on the dorsal border of the nares: absent (0); present (1). (Fernández, 2007:character 2).

9. *Processus narialis of the maxilla in lateral view: absent (0); present (1). This character replaces Fernández's (2007:375) character 0 "premaxilla-lacrimal contact below the external nares", which had 3 states: 'no,' 'narrow,' and 'broad.' The distinction between latter two is subjective.

10. Processus supranarialis of the premaxilla: present (0); absent (1) (Maisch and Matzke, 2000b:character 10).

11. *Processus narialis of prefrontal: absent (0); present (1).

12. Anterior margin of the jugal: tapering, running between the lacrimal and maxilla (0); broad and fanlike, covering large area of maxilla ventrolaterally (1) (Druckenmiller and Maxwell, 2010:character 6).

13. Sagittal eminence: present (0); absent (1) (Fernández, 2007:character 5, inverted codings).

14. *Processus temporalis of the frontal: absent (0); present (1). Motani (1999) introduced a character related to the contact between the nasal and the parietal lateral to the frontal, in dorsal view. That contact is present in some Temnodontosaurus specimens and in Stenopterygius. However, the absence of this contact might have different origins, either by a medial process of the postfrontal, like in Ichthyosaurus, either by a lateral process of the frontal, like in P. australis, Aegirosaurus, and Sveltonectes, or both, like in Ophthalmosaurus (McGowan, 1973; Kirton, 1983; Bardet and Fernández, 2000; Kear, 2005; Kolb and Sander, 2009). Thus, this character state is obtained by different processes, and does not carry any phylogenetic signal. Consequently, a new character is proposed here, based on the presence or absence of a clearly developed processus temporalis of the frontal, forming the anteromedial edge of the supratemporal fenestra.

15. Supratemporal-postorbital contact: absent (0); present (1) (Sander, 2000:character 27).

16. *Squamosal shape: triangular (0); squared (1); squamosal absent (2). Maisch and Matzke (2000a) showed some specimens of Ichthyosaurus retained a squamosal.

17. Quadratojugal exposure: extensive (0); small, largely covered by squamosal and postorbital (1) (modified from Maisch and Matzke, 2000b:character 30). 
18. *Basipterygoid processes: short, giving the basisphenoid a square outline in dorsal view (0); markedly expanded laterally, being wing-like, giving the basisphenoid a marked pentagonal shape in dorsal view (1).

19. Extracondylar area of the basioccipital: wide (0); reduced but still present ventrally and laterally (1); extremely reduced, being nonexistent at least ventrally (2) (Fernández, 2007:character 10, modified).

20. Basioccipital peg: present (0); absent (1) (Motani, 1999:character 29, modified).

21. Stapes proximal head: slender, much smaller than opisthotic proximal head (0); massive, as large or larger than opisthotic (1) (Sander, 2000:character 34, modified). Stenopterygius is the only Liassic ichthyosaur to display the derived state (e.g. Fraas, 1891:table 2 II [S. quadriscissus according to Maisch, 2008:233]; Owen, 1840 [S. triscissus according to Maisch, 2008, p. 237]; Dechaseaux, 1954 [S. triscissus according to Maisch, 2008; M. Maisch, pers. comm., 2010]).

22. Angular lateral exposure: much smaller than surangular exposure (0); extensive (1) (Motani, 1999: character 32, inverted coding).

\section{Axial skeleton}

23. 'Cervical' centra (diapophysis-neural arch facet contact) extend up to middle dorsal region (0); anterior dorsal region (1) (Sander, 2000:character 66, modified).

24. Posterior dorsal/anterior caudal centra: 3.5 times or less as high as long (0); four times or more as high as long (1) (Maxwell, 2010:character 15, inverted codings).

25. Tail fin centra: strongly laterally compressed (0); as wide as high (1) (Maxwell, 2010: character 16).

26. Neural spines of atlas-axis: completely overlapping, may be fused (0); functionally separate, never fused (1) (Druckenmiller and Maxwell, 2010:character 26).

27. Chevrons in the apical region: present (0); lost (1) (Sander, 2000:character 72).

\section{Shoulder girdle}

28. *Prominent acromion process of the scapula: absent (0); present (1).

29. *Anteromedial process of the coracoid: present (0); absent (1).

\section{Forefin}

30. Plate-like dorsal ridge on humerus: absent (0); present (1) (Motani, 1999:character 56).

31. *Protruding, strongly developed deltopectoral crest on humerus, matching in height the trochanter dorsalis, and bordered by concave areas: absent (0); present (1). This character may tentatively be coded as derived for Caypullisaurus based on the single fully prepared humerus figured in Fernández (1998:fig. 2), which shows strongly developed trochanters.

32. Humerus distal and proximal ends in dorsal view (thus regardless of the size of the dorsal and ventral processes): distal end wider than proximal end (0); nearly equal or proximal end slightly wider than distal end (Motani, 1999:character 55, modified).

33. Humerus anterodistal facet for accessory zeugopodial element anterior to radius: absent (0); present (1) (Godefroit, 1993:character 10, modified).

34. *Posteriorly deflected ulnar facet: absent (0); present (1).

35. Humerus/intermedium contact: absent (0); present (1). (Fernández, 2007:character 15)

36. Manual pisiform: absent (0); present (1) (Motani, 1999:character 67, inverted codings).

37. Notching of the anterior facet of the leading edge elements of the forefin in adults: present (0); absent (1) (Motani, 1999:characters 59 and 65, modified). Motani's (1999) characters 59 and 65 were clearly linked to each other in our data matrix, and have therefore been combined in the present analysis. 
38. Posterior enlargement of the forefin: number of postaxial accessory 'complete' digits: none (0); one (1), two or more (2). (Maisch and Matzke, 2000b:character 89, modified).

39. Preaxial accessory digits on forefin: absent (0); present (1) (Maisch and Matzke, 2000b:character 91). Since the reappraisal of the forefin of Caypullisaurus (Fernández, 2001), there is no current evidence of two well developed preaxial digits in this taxa: Fernández (2007) mentioned that the anterior extrazeugopodial element supports two digits, but one of them is the 'radiale' digit (II). At the current state of knowledge, the presence of two preaxial digits remains a valid autapomorphy of Platypterygius (Maxwell and Caldwell, 2006a; VF, pers. obs.).

40. *Longipinnate or latipinnate forefin construction: one (0); two (1) digit(s) directly supported by the intermedium.

41. Zeugo- to autopodial elements flattened and plate-like (0); strongly thickened (1) (Maisch and Matzke, 2000b:character 94). According to Maisch and Matzke (2000a), no Liassic ichthyosaur exhibits the derived state. However, this is not restricted to Ophthalmosauridae, as Chacaicosaurus cayi presents clearly thickened phalanges as well (Fernández, 1994). This reinforces the status of Chacaicosaurus as an intermediate form between Stenopterygius and Ophthalmosauridae (see Maisch and Matzke, 2000a).

42. Tightly packed rectangular phalanges: absent, phalanges are mostly rounded (0); present (1) (Maisch and Matzke, 2000b:character 102, modified).

43. *Digital bifurcation: absent (0); frequently occurs in digit IV (1).

\section{Pelvic girdle}

44. Ischium-pubis fusion in adults: absent or present only proximally (0); present with an obturator foramen (1); present with no obturator foramen (Mazin, 1982:character 13, modified).

45. Ischium or ischiopubis shape: plate-like, flattened (0); rod-like (1) (Motani, 1999:character 87, modified).

\section{Hindfin}

46. *Prominent, ridge-like dorsal and ventral processes demarked from the head of the femur and extending up to mid-shaft: absent (0); present (1).

47. Astragalus/femoral contact: absent (0); present (1) (Maxwell, 2010:character 33).

48. *Femur anterodistal facet for accessory zeugopodial element anterior to tibia: absent (0); present (1). This character replaces character 32 of Maxwell (2010:411) "Number of articular facets on distal femur" because these facets are not homologous (compare Kolb and Sander, 2009; Maxwell and Kear, 2010; Zammit et al., 2010).

49. Tibia peripheral shaft in adults: notched (0); straight (1) (Motani, 1999:character 92, modified).

50. *Postaxial accessory digit: absent (0); present (1). 
APPENDIX 2. Character-taxon matrix used for phylogenetic analysis of Thunnosauria, with Temnodontosaurus as the outgroup. Abbreviations: A, polymorphism for states 0 and $1 ; \mathbf{B}$, polymorphism for states 0 and 2 .

\begin{tabular}{|c|c|c|c|c|c|}
\hline axon & 10 & 20 & 30 & 40 & 50 \\
\hline Temnodontosaurus & 0000000000 & 0000000000 & 0000000000 & 0000000000 & 0000000000 \\
\hline Ichthyosaurus & $000000100 \mathrm{~A}$ & $00001 \mathrm{~B} 1000$ & 0010000000 & $01000 A 1 A 01$ & 0110100010 \\
\hline Stenopterygius & A00A1110A0 & 0000001000 & $10111-1100$ & $00000 \mathrm{~A} 0000$ & $00111-0000$ \\
\hline o. icenicus & 0101011111 & 1110001011 & 1111011101 & 0111011111 & 1001110010 \\
\hline Chacaicosaurus & $---1---0--$ & --------00 & ---------0 & $--0-010000$ & $100-------$ \\
\hline Brachypterygius & $01000-0-00$ & $-1-----121$ & $-10----1-1$ & 1101111111 & $100------1$ \\
\hline Arthropterygius & ---------- & -------020 & $1--11-1-01$ & $01110-1--0$ & $-----00---$ \\
\hline Mollesaurus & $----1--00-$ & $0----11-11$ & $1-00------$ & ---------- & ---------1 \\
\hline Caypullisaurus & $---10-0 \mathrm{~A} 00$ & $0---110---$ & $-110---111$ & 1110011210 & $1102-10-11$ \\
\hline Aegirosaurus & A0001-1101 & $11-1001---$ & $-1-------1$ & -100111111 & $-1021-0011$ \\
\hline P. australis & 0110000010 & 0101020121 & 1110111111 & 1110011210 & 1102010111 \\
\hline P. hercynicus & 01100-100- & 01110A1-2- & $1---1-1011$ & 1110011210 & $110--1101-$ \\
\hline Maiaspondylus & $11100-1-01$ & $-1-----0--$ & $--10-----1$ & $-10011-1-0$ & $-10---10--$ \\
\hline Athabascasaurus & $10-00-0011$ & $-110010-2-$ & $11-0-1----$ & ---------- & $---201----$ \\
\hline Sveltonectes & $10101-1101$ & $1111---021$ & $11000-1101$ & $11000-1111$ & $1102-1011$ \\
\hline
\end{tabular}


SUPPLEMENTARY INFORMATION 

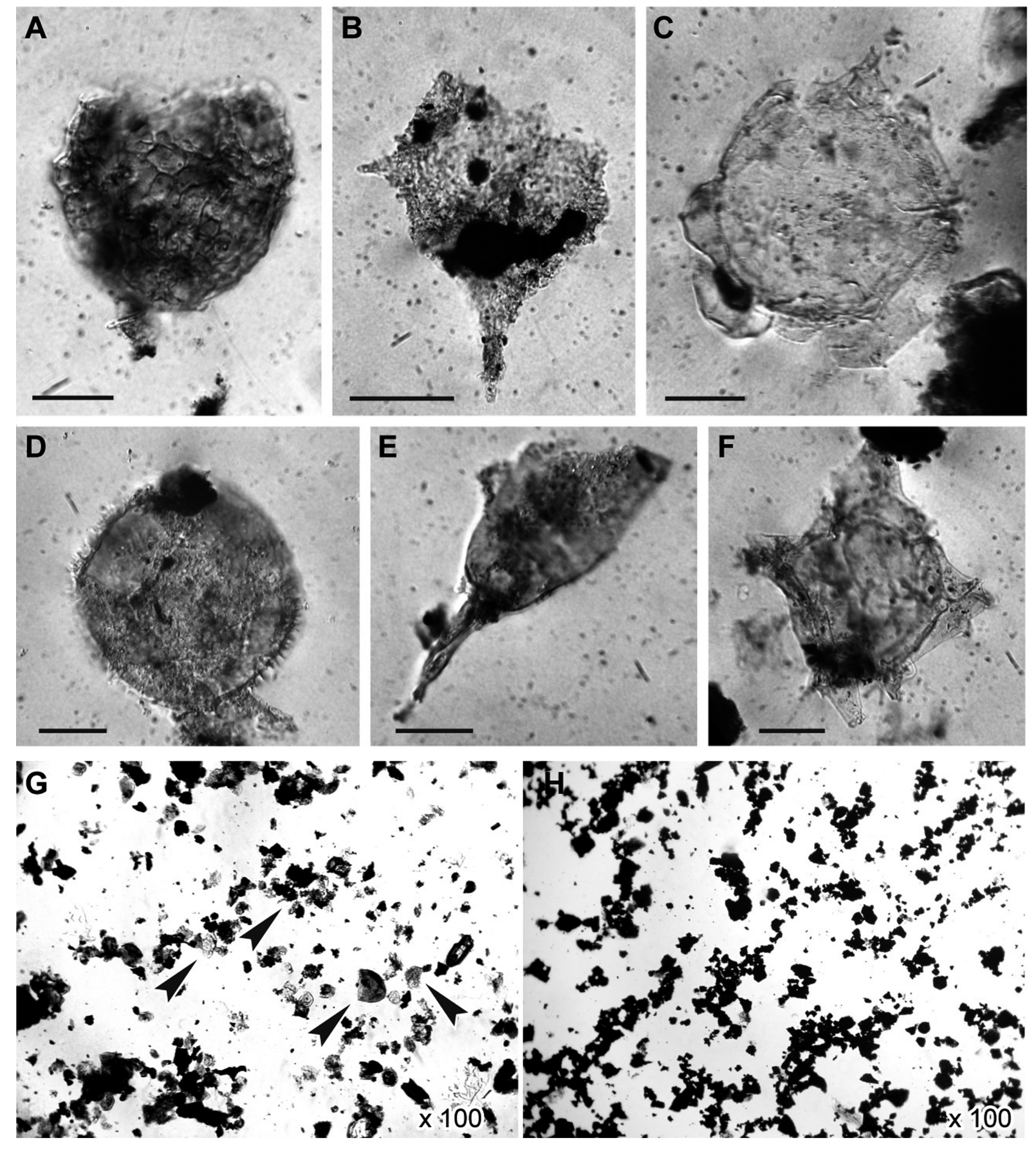

FIGURE 1S. Selected dinocyst taxa extracted from IRSNB R269. A, Cassiculosphaeridia magna, cyst without operculum, $56 \mu \mathrm{m}$, slide 67174 (rostrum). B, Pseudoceratium pelliferum, cyst without operculum, $64 \mu \mathrm{m}$, slide 67654 (phalange). C, Sirmiodinium grossii, cyst with operculum, $80 \mu \mathrm{m}$, slide 67176 (indet. bone). D, Trichodinium speetonense, general view, $68 \mu \mathrm{m}$, slide 67174 (rostrum). E, Batioladinium longicornutum, cyst without operculum, $90 \mu \mathrm{m}$, slide 67176 (indet. bone). F, Phoberocysta neocomica, cyst with operculum, $88 \mu \mathrm{m}$, slide 67646 (neural arc). G, typical palynofacies: matrix with clear organic mater and dinoflagellate cysts (arrows), slide 67174 (rostrum). $\mathbf{H}$, unusual palynofacies from the dismissed centrum: matrix with only black particles, slide 67177 (centrum 3). Scale bars equal $20 \mu \mathrm{m}$. 
TABLE 1S. Organic microfossil assemblage extracted from IRSNB R269. See Fensome and Williams (2004) for the systematical authorship references.

\section{Organic microfossil assemblage}

\section{Dinokysts}

Achomosphaera neptunii (Eisenack, 1958a)

Davey and Williams, 1966

Kleithriasphaeridium corrugatum Davey, 1974

Apteodinium granulatum Eisenack, 1958 emend

Sarjeant, 1985 emend. Lucas-Clark, 1987

Kleithriasphaeridium eoinodes (Eisenack, 1958)

Davey, 1974 emend. Sarjeant, 1985

Batioladinium cf. pelliferum (Alberti, 1961)

Brideaux, 1975

Kleithrisphaeridium fasciatum (Davey and Williams, 1966) Davey, 1974

Batioladinium longifurcatum (Alberti, 1961)

Brideaux, 1975 emend. Below, 1990

Meiourogonyaulas stoveri Millioud, 1969

Batioladinium longicornutum (Alberti, 1961)

Brideaux 1975 emend. Below, 1990

Odontochitina operculata (Wetzel, 1933)

Deflandre and Cookson, 1955

Cassiculosphaeridia magna Davey, 1974

emend. Harding, 1990

Oligosphaeridium abaculum Davey, 1979

Chlamydophorella nyei Cookson and Eisenack, 1958

Oligosphaeridium dividum Williams, 1978

Circulodinium distinctum (Deflandre and

Cookson, 1955) Jansonius, 1986

Phoberocysta neocomica (Gocht, 1957)

Millioud, 1969

Coronifera oceanica Cookson and Eisenack, 1958.

Cribroperidinium palla (Sarjeant, 1966)

Helenes, 1984

Cribroperidinium sepimentum Neale and

Sarjeant, 1962

Pseudoceratium pelliferum Gocht, 1957

Rhynchodiniopsis fimbriata (Duxbury, 1980)

Sarjeant, 1982

Scriniodinium campanula subsp. campanula (Goch, 1959) Vozzhennikova, 1967

Dapsilidinium warrenii (Habib, 1976) Lentin and Williams, 1981

Sepispinula $\mathrm{sp}$.

Downiesphaeridinium sp.

Sirmiodinium grossii (Alberti, 1961) Warren, 1973

Dingodinium cerviculum Cookson and Eisenack, 1958.

Taniosphaeridium boletus Davey, 1974 
TABLE S1. Continued.

Dissiliodinium $\mathrm{sp}$.

Hystrichodinium pulchrum Deflandre, 1935

Isthmocystis distincta Duxburry, 1979

Kiokansium unituberculatum (Tash in Tasch et al., 1964) Stover and Evitt, 1978
Trichodinium speetonense Davey, 1974

Wrevittia helicoidea (Eisenak and Cookson, 1960) Helenes and Lucas-Clark, 1997

Spiniferites sp.

Prasinophyta

Pterospermella sp. Eisenack, 1972

\section{DIFFERENTIAL DIAGNOSIS}

Sveltonectes insolitus is also characterized by a unique combination of features: broad premaxillalacrimal contact ventrally to the external naris (shared with Mollesaurus, Aegirosaurus, Caypullisaurus, and Platypterygius [except $P$. americanus and $P$. australis]: Romer, 1968; Kear, 2005; Fernández, 2007); extremely reduced maxilla extending anteriorly as far as the anterior border of nares (shared with some European specimens of Platypterygius: Sirotti and Papazzoni, 2002; VF, pers. obs.; Plutoniosaurus bedengensis: Efimov, 1997; Aegirosaurus: Bardet and Fernández, 2000); slender snout (snout depth ratio: 0.47, in between P. americanus (0.43) and O. natans (0.54); McGowan, 1976); moderately large orbit (mean orbital ratio: 0.18; similar to Brachypterygius:

McGowan, 1976); prefrontal participates in the posterodorsal border of the external naris (shared with Aegirosaurus: Bardet and Fernández, 2000); flat, vertically-oriented anterior surface of the basioccipital (shared with Brachypterygius: McGowan and Motani, 2003; Arthropterygius: Maxwell, 2010; P. australis: Kear, 2005); dental roots with squared cross-section (shared with Undorosaurus: Efimov, 1999, Platypterygius: Bardet, 1990; Maiaspondylus: Maxwell and Caldwell, 2006); very high number of "cervical" centra (22, as in "Otschevia" alekseevi: Arkhangelsky, 2001); no haemapophyseal facets on apical (shared with Ophthalmosaurus natans: Gilmore, 1905; Platypterygius hercynicus; Kolb and Sander, 2009) and postflexural centra; humerus with two distal facets, for radius and ulna (shared with Nannopterygius: Hulke, 1871; McGowan and Motani, 2003; Platypterygius platydactylus: Broili, 1907; Maxwell and Kear, 2010; P. campylodon: Kiprijanoff, 1881; Kear and Barrett, 2007; Kolb and Sander, 2009; Maxwell and Kear, 2010; VF, pers. obs.); humerus with very prominent dorsal and ventral trochanters (shared with Platypterygius: Kuhn, 1946; McGowan, 1972; Wade, 1984, 1990; Choo, 1999; Kolb and Sander, 2009); tightly packed, brick-like phalanges (shared with Platypterygius: McGowan and Motani, 2003, Maiaspondylus: Maxwell and Caldwell, 2006; Caypullisaurus: Fernández, 2001); relatively long hindfins, being two-third the size of the forefin (shared with Undorosaurus: Efimov, 1999; Maisch and Matzke, 2000); presence of one preaxial accessory digit in the hindfin (shared with P. australis: Zammit et al., 2010).

\section{LITERATURE CITED}


Arkhangelsky, M. S. 2001. On a new ichthyosaur of the genus Otschevia from the Volgian Stage of the Volga Region near Ulyanovsk. Paleontological Journal 35:629-634.

Bardet, N. 1990. Dental cross-section in Cretaceous Ichthyopterygia: systematic implications. Geobios 23:169-172.

Bardet, N., and M. Fernández. 2000. A new ichthyosaur from the Upper Jurassic lithographic limestones of Bavaria. Journal of Paleontology 74:503-511.

Broili, F. 1907. Ein neüer Ichthyosaurus aus der norddeutschen Kreide. Palaeontographica 54:139162.

Choo, B. 1999. Cretaceous ichthyosaurs from Western Australia. Records of the Western Australian Museum, Supplement 57:207-218.

Efimov, V. M. 1997. A new genus of ichthyosaurs from the Late Cretaceous of the Ulyanovsk Volga region. Paleontological Journal 31:422-426.

Efimov, V. M. 1999. A new family of ichthyosaurs, the Undorosauridae fam. nov. from the Volgian stage of the European part of Russia. Paleontological Journal 33:174-181.

Fensome, R. A., and G. L. Williams. 2004. The Lentin And Williams index of fossil dinoflagellates, 2004 edition, AASP Contributions Series. American Association of Stratigraphic Palynologists Foundation, 909 pp.

Fernández, M. 2001. Dorsal or ventral? Homologies of the forefin of Caypullisaurus (Ichthyosauria: Ophthalmosauria). Journal of Vertebrate Paleontology 21:515-520.

Fernández, M. 2007. Redescription and phylogenetic position of Caypullisaurus (Ichthyosauria: Ophthalmosauridae). Journal of Paleontology 81:368-375.

Gilmore, C. W. 1905. Osteology of Baptanodon (Marsh). Memoirs of the Carnegie Museum II:77129.

Hulke, J. W. 1871. Note on an Ichthyosaurus (I. enthekiodon) from the Kimmeridge Bay, Dorset. Quarterly Journal of the Geological Society of London 27:440-441.

Kear, B. P. 2005. Cranial morphology of Platypterygius longmani Wade, 1990 (Reptilia: Ichthyosauria) from the Lower Cretaceous of Australia. Zoological Journal of the Linnean Society 145:583-622.

Kear, B. P., and P. M. Barrett. 2007: Reassessment of the English Cretaceous ichthyosaur Platypterygius campylodon. Symposium of Vertebrate Palaeontology and Comparative Anatomy, Glasgow, 2007:38.

Kiprijanoff, W. 1881. Studien über die Fossilen Reptilien Russlands. Theil 1 Gattung Ichthyosaurus König aus dem severischen Sandstein oder Osteolith de Kreide-Gruppe. Mémoires de l'Académie impériale des Sciences de St.-Pétersbourg, VIIe série 28:1-103.

Kolb, C., and P. M. Sander. 2009. Redescription of the ichthyosaur Platypterygius hercynicus (Kuhn 1946) from the Lower Cretaceous of Salzgitter (Lower Saxony, Germany). Palaeontographica Abteilung a-Palaozoologie-Stratigraphie 288:151-192.

Kuhn, O. 1946. Ein skelett von Ichthyosaurus hercynicus n. sp. aus dem Aptien von Gitter. Berichte der Naturforschenden Gesellschaft Bamberg 29:69-82.

Maisch, M. W., and A. T. Matzke. 2000. The Ichthyosauria. Stuttgarter Beiträge zur Naturkunde: Serie B Geologie und Paläontologie 298:1-159.

Maxwell, E. E. 2010. Generic reassignment of an ichthyosaur from the Queen Elizabeth Islands, Northwest Territories, Canada. Journal of Vertebrate Paleontology 30:403-415.

Maxwell, E. E., and M. W. Caldwell. 2006. A new genus of ichthyosaur from the Lower Cretaceous of Western Canada. Palaeontology 49:1043-1052. 
Maxwell, E. E., and B. P. Kear. 2010. Postcranial anatomy of Platypterygius americanus (Reptilia: Ichthyosauria) from the Cretaceous of Wyoming. Journal of Vertebrate Paleontology 30:1059-1068.

McGowan, C. 1972. The systematics of Cretaceous ichthyosaurs with particuliar reference to the material from North America. Contributions to Geology 11:9-29.

McGowan, C. 1976. The description and phenetic relationships of a new ichthyosaur genus from the Upper Jurassic of England. Canadian Journal of Earth Sciences 13:668-683.

McGowan, C., and R. Motani. 2003. Handbook of Paleoherpetology. Part 8 Ichthyopterygia; in H.-D. Sues (ed.). Verlag Dr. Friedrich Pfeil, München, 175 pp.

Romer, A. S. 1968. An ichthyosaur skull from the Cretaceous of Wyoming. Contributions to geology, Wyoming University 7:27-41.

Sirotti, A., and C. Papazzoni. 2002. On the Cretaceous ichthyosaur remains from the Northern Apennines (Italy). Bollettino della Societa Paleontologica Italiana 41:237-248.

Wade, M. 1984. Platypterygius australis, an Australian Cretaceous ichthyosaur. Lethaia 17:99-113.

Wade, M. 1990. A review of the Australian Cretaceous longipinnate ichthyosaur Platypterygius (Ichthyosauria, Ichthyopterygia). Memoirs of the Queensland Museum 28:115-137.

Zammit, M., R. M. Norris, and B. P. Kear. 2010. The Australian Cretaceous ichthyosaur Platypterygius australis: a description and review of postcranial remains. Journal of Vertebrate Paleontology 30:1726-1735. 